\title{
Multi-Stakeholder Initiatives on Sustainability: A Cross-Disciplinary Review and Research Agenda for Business Ethics
}

\author{
Frank G.A. de Bakker \\ IESEG School of Management \\ LEM-CNRS 9221
}

Andreas Rasche

Copenhagen Business School

Stockholm School of Economics

\section{Stefano Ponte}

Copenhagen Business School

\begin{abstract}
Although the literature on multi-stakeholder initiatives for sustainability has grown in recent years, it is scattered across several academic fields, making it hard to ascertain how individual disciplines, such as business ethics, can further contribute to the debate. Based on an extensive review of the literature on certification and principle-based MSIs for sustainability ( $n=293$ articles), we show that the scholarly debate rests on three broad themes (the "3Is"): the input into creating and governing MSIs; the institutionalization of MSIs; and the impact that relevant initiatives create. While our discussion reveals the theoretical underpinnings of the 3Is, it also shows that a number of research challenges related to business ethics remain unaddressed. We unpack these challenges and suggest how scholars can utilize theoretical insights in business ethics to push the boundaries of the field. Finally, we also discuss what business ethics research can gain from theory development in the MSI field.
\end{abstract}

KEY WORDS: multi-stakeholder initiatives (MSIs), sustainability, institutionalization, legitimacy, business ethics, management studies

$\mathrm{T}$ he governance of sustainability in production, trade, and consumption takes place through a complex system of international and national regulations overlapping with emerging private and hybrid forms. While in the past it was national governments and international organizations that were mainly in charge of regulation, private actors have played an increasingly powerful role in recent decades. Within this context, multi-stakeholder initiatives (MSIs), such as the Roundtable for Sustainable Palm Oil (RSPO) or the Marine Stewardship Council (MSC), have emerged as part and parcel of the private regulation of (global) corporate conduct (Fransen \& Kolk, 2007; Lambin \& Thorlakson, 2018; Vogel, 2008). MSIs have proliferated as 
different stakeholder groups are increasingly asking firms to be more accountable, especially in sectors like agriculture, fishing, and forestry where global supply chains are a dominant mode of organization (Bäckstrand, 2006). Although official statistics do not exist, the scale and scope of MSIs is significant; a recent comparison of forty-five initiatives revealed that these MSIs alone regulate over nine thousand companies (including sixty-five Fortune Global 500 businesses) in more than 170 countries on six continents (MSI Integrity, 2017).

MSIs develop social and/or environmental standards and "have participants from both business and societal interest groups as members and governance structures allowing for an equal possibility of input among the different partners in steering the initiative" (Fransen, 2012: 166). This differentiates MSIs from other forms of private regulation, such as firm-specific codes of conduct or business-driven initiatives. MSIs also differ from rules set by international standard-setting bodies, such as standards set by the International Organisation for Standardization (ISO). Some MSIs are created around certification systems (e.g., the Forest Stewardship Council [FSC]), whereas others promote broader principles without any certification (e.g., the UN Global Compact). While a vast literature has developed around MSIs, we are lacking a review that generates ideas for new theory development within and through business ethics - "the study of business situations, activities, and decisions where issues of right and wrong are addressed" (Crane \& Matten, 2007: 5).

The aim of this article is to review the scholarly literature on different types of MSIs across academic disciplines, highlight their various theoretical underpinnings, and indicate the research challenges that remain unaddressed from a business ethics perspective. The main research questions that guide our analysis are: Which themes constitute the cross-disciplinary literature around MSIs for sustainability? How can business ethics contribute to this literature in the future? Our review is motivated by two observations.

First, the discussion of MSIs is scattered across academic disciplines, making it difficult to see which themes are addressed and how this is done. In collecting and interrogating contributions from different academic fields, our study provides a comprehensive review of MSIs. We offer a holistic and multidisiplinary understanding of MSIs as a relevant object of analysis, and show in what ways business ethicists can contribute to future debates and how business ethics could be informed by studying MSIs. Gaining a better understanding of MSIs within business ethics is necessary because a number of problems related to MSIs deal with normative questions and hence require explicit ethical reflection (e.g., related to norm justification). Despite the high relevance of business ethics scholarship for MSIs, we have found only limited scholarly work on relevant initiatives in the business ethics field (see, e.g., Gilbert \& Rasche, 2007; Williams, 2004).

Second, and possibly as a result of its embeddedness in multiple disciplines, the discourse on MSIs remains weakly theorized in some areas. Many contributions merely focus on reporting results and hence remain fairly descriptive, not offering a solid contribution to theory development, that is, not contributing to "the statement of concepts and their interrelationships that shows how and/or why a phenomenon occurs" (Corley \& Gioia, 2011: 12), or to theory testing. Indeed, while scholars have 
gained rich empirical insights on MSIs' functioning (e.g., Raynolds, 2014; Riisgaard, 2011), these insights have not been sufficiently leveraged to develop meaningful theoretical contributions, offering new explanations or insights beyond the MSI studied. Many articles, for instance, describe MSI governance structures without providing a discussion on their implications for theory (e.g., Partzsch, 2011; Schepers, 2010). Since many MSI studies are not theoretically driven, authors often do not discuss whether their empirical results fundamentally support or challenge relevant theoretical concepts. Based on our review, we suggest several ways in which scholars can better employ existing theoretical insights from business ethics to address research challenges within the MSI domain.

Our cross-disciplinary review ( $n=293$ articles) maps the existing knowledge on MSIs in detail. Our findings provide three key contributions to research in the MSI domain. First, we uncover the basic characteristics of research on MSIs. We sketch its growth and show whether and to what extent certification and principle-based MSIs have been discussed in different disciplines, and which theories and methods are predominantly used in the field. These basic characteristics provide a background against which current and future research is discussed.

Second, we inductively derive a framework from an analysis of the 293 articles, demonstrating that MSI research across various disciplines rests on three main themes, which we jointly term the "3Is": the input into creating and governing MSIs; the institutionalization of MSIs; and the impact that relevant initiatives have or do not have. Organizing the MSI discourse around the 3Is unravels those theoretical perspectives that have informed the debate so far, and unpacks aspects that have been largely neglected by business ethics research to date. We uncover three research challenges within the 3Is and one research challenge across the 3Is where the theoretical knowledge gaps are greatest: (1) With regard to input, while the current literature has shown the need to communicatively justify the norms that underlie MSIs (e.g., Mena \& Palazzo, 2012), it puts too much emphasis on deliberative structures within relevant initiatives and thereby disregards the larger regulatory systems in which MSIs are embedded. (2) With regard to institutionalization, the current literature primarily focuses on utilitarian reasoning when explaining why firms adopt MSIs and thereby neglects other types of motivations (e.g., deontological reasoning). (3) With regard to impact, the current literature hardly clarifies how different actors mobilize different moral legitimacy criteria to justify MSIs' impact, and how disputes between actors with different criteria can be resolved (for an exception, see Gilbert \& Rasche, 2007). (4) Finally, with regard to interaction effects between the 3Is, the current literature neglects the micro-level foundations of the individual ethical leadership that is required to initiate moral action within and around MSIs.

Third, we provide theoretical advances by showing how future business ethics research can address the four identified research challenges. What do we mean by theoretical advances? On the one hand, we show that current theoretical approaches (i.e., those used by ethicists who study MSIs) could be applied to new research questions; for instance, we argue that deliberative democracy thinking can be applied to questions that concern MSIs' embeddedness in larger regulatory 
systems, thus introducing new research questions into the field while also expanding current theoretical approaches that have been used by business ethicists so far. On the other hand, we highlight that new theoretical approaches (i.e., those currently not used to study MSIs) can be applied to new research questions that arise within the 3Is - for instance, by showing how the economies of worth literature could be used by business ethics scholars to discuss the legitimization of MSIs' impact. This type of theoretical advance introduces new theoretical frameworks and new research questions relevant to business ethics into the larger MSI discourse. While this section asks what MSI scholarship can gain from business ethics, the section that follows debates what business ethics research (e.g., stakeholder theory) can learn from MSI studies.

\section{METHOD}

\section{Unit of Analysis-MSIs for Sustainability}

To ensure feasibility in scope, our review deals with MSIs that address social and/ or environmental issues. We view MSIs as voluntary rule-systems for sustainability that are governed by stakeholders who jointly cross the profit/nonprofit and state/ non-state boundaries (Fransen, 2012; Fransen \& Kolk, 2007; Gilbert et al., 2011). Our review distinguishes between two types of MSIs: certification-based MSIs and principle-based MSIs. Certification MSIs place emphasis on compliance with predefined rules and contain verification mechanisms. Verification happens through certification procedures during which auditors check production facilities. Often these MSIs offer certification labels on the final product to signal sustainability content to consumers. Prominent examples of certification MSIs include the FSC, the MSC, Fairtrade, and the RSPO. Principle-based MSIs include initiatives that promote broader business principles to which firms can sign up for without undergoing verification. Such MSIs focus on offering a framework to bring together likeminded firms around certain foundational values and guidelines, and to improve the disclosure of firms' social/environmental performance (e.g., by offering reporting principles). Prominent examples of such MSIs include the UN Global Compact (UNGC), the Global Reporting Initiative (GRI), and the Principles for Responsible Investment (PRI).

Our analysis excludes other initiatives that have emerged under the umbrella of private regulation such as business/industry-driven initiatives having either no or minimal multi-stakeholder representation. ${ }^{1}$ We also exclude studies on ISO 9001 and ISO 14001, since ISO standards are set by technical working groups that do not follow a multi-stakeholder model (Tamm-Hallström, 2008). ${ }^{2}$ Finally, we exclude studies that deal with company-specific codes of conduct as they are not applicable beyond the scope of single corporations and usually do not rely on a multi-stakeholder model. ${ }^{3}$

We excluded these three types of private regulation in order to keep the scope of the review manageable. Research on certification and principle-based MSIs constitutes a large body of work across a number of disciplines. Other types of private regulation often differ significantly from MSIs and hence would make comparisons difficult. ISO standards, for example, emphasize the role of national standards associations 
and technical working groups, both of which differ from a multi-stakeholder model (see Heras-Saizarbitoria \& Boiral, 2013). While we exclude studies that dealt exclusively with other types of private regulation, we include those comparing MSIs to other regulatory models - for instance, a number of articles compare business-driven initiatives with MSIs (e.g., Cashore et al., 2005; Fransen, 2012).

\section{Exclusion and Inclusion Criteria}

Establishing a Universe of Potentially Relevant Articles

This process consisted of two stages. In the first stage, we drafted a list of twenty-one journals from different disciplines (Table 1). Based on our own experience working in the field, we considered these outlets as key contributors to scholarly work on MSIs across disciplines. We based our selection of management journals and business ethics journals on previous reviews of the literature on social/environmental issues (e.g., Aguinis \& Glavas, 2012; Frynas \& Yamahaki, 2016). Because of the labor-intensive nature of manually screening academic journals, we limited our initial search to six general management and four business ethics journals. The journals

Table 1: List of Academic Journals Screened Manually

\begin{tabular}{|c|c|c|c|}
\hline No. & Journal & Disciplinary Focus & No. of Articles \\
\hline 1 & Academy of Management Journal & General Management & 2 \\
\hline 2 & Academy of Management Review & General Management & 2 \\
\hline 3 & Administrative Science Quarterly & General Management & 0 \\
\hline 4 & Journal of Management Studies & General Management & 4 \\
\hline 5 & Organization Science & General Management & 2 \\
\hline 6 & Organization Studies & General Management & 3 \\
\hline 7 & Business Ethics Quarterly & Business Ethics & 4 \\
\hline 8 & Business and Society & Business Ethics & 13 \\
\hline 9 & Corporate Governance: An Intl. Review & Business Ethics & 0 \\
\hline 10 & Journal of Business Ethics & Business Ethics & 33 \\
\hline 11 & Agriculture \& Human Values & Food and Agriculture & 18 \\
\hline 12 & Int. Food and Agribusiness Mngt. Review & Food and Agriculture & 4 \\
\hline 13 & Ecology and Society & Environmental Studies & 4 \\
\hline 14 & Journal of Cleaner Production & Environmental Studies & 16 \\
\hline 15 & Ecological Economics & Economics & 4 \\
\hline 16 & Environment and Planning A & Geography & 2 \\
\hline 17 & Geoforum & Geography & 9 \\
\hline 18 & Global Governance & Political Science & 3 \\
\hline 19 & Regulation and Governance & Political Science & 10 \\
\hline 20 & Third World Quarterly & Development Studies & 4 \\
\hline \multirow[t]{2}{*}{21} & World Development & Development Studies & 12 \\
\hline & Total & & 149 \\
\hline
\end{tabular}


in other disciplines were selected based on our knowledge of leading outlets that had published work on MSIs. The diverse disciplinary background of the authors contributed to achieving a balanced list. We manually checked all volumes of the selected journals for articles published within a seventeen-year period (2000-2016) and collected all papers discussing certification MSIs and principle-based MSIs. We included only papers that dealt with MSIs as key aspects of their analysis rather than merely mentioning them in passing. We used the year 2000 as the cutoff point for our analysis, since a number of MSIs were launched either after or shortly before the new millennium (e.g., the UNGCand the GRI in 2000; the RSPO in 2004; and SA 8000 and the MSC in 1997). As academic studies are usually not published immediately after an event, such as the launch of an MSI, we considered the year 2000 as a reasonable cutoff point. This first stage resulted in a set of 149 papers and was helpful in fine-tuning the second stage.

In the second stage, we conducted searches in the ISI Web of Science (Core Collection) using the following search strings: certification*, multistakeholder*, multi-stakeholder*, roundtable*, sustainability standard*, CSR standard*, and responsibility principle*. These keywords were chosen based on our initial screening of the articles we had identified through the manual search. We viewed this more "open" search as vital, since the literature on MSIs is spread across numerous journals and academic disciplines and therefore any predefined list of journals would have limited the comprehensiveness of our cross-disciplinary review. We decided not to perform key-word searches on individual MSIs, because we were interested in understanding the more general characteristics underlying MSI processes and the ways in which these were being explained in different scholarly domains. This open search resulted in a list of 24,430 papers. The vast majority of these papers (over 95 percent) discussed certification and standards in a variety of domains beyond our scope. We dismissed duplicates (papers already found in stage one) and papers that were evidently not focused on multi-stakeholder participation (e.g., papers with a technical focus). This led to a long-list of about 3,500 papers. We then narrowed down this list by looking at the title, key words, and abstract of each paper. This step was undertaken to determine whether an entry really addressed MSIs in the sustainability field. This selection process led to a set of 319 papers. Combining the sets of papers from the first and second stages $(149+319)$ yielded an overall set of 468 papers, which we considered to be reflective of the broad universe of potentially relevant articles.

\section{Narrowing Down the Universe of Relevant Articles}

To further narrow down the universe of relevant articles we examined each entry in more detail (by looking at the introduction and speed-reading the full article, when necessary) to determine whether it should remain in the dataset. Each entry was assessed by at least two of the authors in relation to: (1) whether it really discussed MSIs or referred to other forms of multi-stakeholder engagement in the context of sustainability; and (2) whether it discussed MSIs in some depth or just mentioned them in passing. The studies removed from our dataset included: papers that appeared 
to be reports of workshops; papers that discussed multi-stakeholder action in other contexts (e.g., in NGO-business partnerships); papers that mentioned MSIs only in passing; editorials briefly mentioning MSIs; and papers that provided technical details relating to a specific industry. Articles in which assessments differed among the authors were discussed with the purpose of reaching a consensus. This second phase resulted in a final dataset of 293 papers, which are listed in an online supplementary appendix.

\section{Thematic Analysis of Relevant Articles}

We started by recording basic data for each article: the journal in which it was published, the year of publication, the main location of empirical work (if relevant), the disciplinary affiliation of the lead author, the method(s) utilized (conceptual, qualitative, quantitative, mixed), the type of MSI (certification, principle-based, both), and the theoretical orientation(s) (if applicable). Each paper was read by at least two of the authors in depth, assigned with an automated randomizer tool. Given the intended contribution of our study and the nature of the underlying data, we deemed qualitative coding to be the most appropriate method for the subsequent thematic analysis of the articles. Our approach therefore could be characterized as an abductive approach in which we applied a "more descriptive formulation of induction that admit[s] the idea of an active reasoner" (Ketokivi \& Mantere, 2010: 319). Informed by our prior knowledge of the field, but open to the rich variety in our data, we aimed to develop an appropriate categorization.

The thematic analysis started with an open coding process (Strauss \& Corbin, 1998). All of the authors reviewed a subset of twenty-five randomly selected papers to identify a series of relevant categories for further analysis, focusing on the identification of keywords and concepts. In the next step we used these keywords and concepts to classify the papers in this subset, keeping an eye out for themes not covered yet. We discussed emerging categories and started to recognize similarities and differences among them. The process at this stage was similar to what Strauss and Corbin (1998) call "axial coding," i.e., a type of second order coding that reduces the number of categories. In doing so, we went back a second time to our subset of data to interrogate our list of categories. This process resulted in twenty main categories that were entered into a codebook (see Table 2). In deriving these categories, we followed the advice given by Bowen (2008: 140) that theoretical saturation is reached when scholars "gather data to the point of diminishing returns, when nothing new is being added." Ultimately, we sought to further elaborate these categories into a limited number of main groups to present the analysis in more structured and intelligible ways, mostly by discussing commonalities and differences between the derived categories. This process resulted in the identification of a smaller set of aspects (the subcategories under the 3Is; see below), which were then grouped into three overall thematic dimensions (i.e., input, institutionalization, and impact) to structure our findings. Each of the remaining papers from our entire dataset were then assigned randomly to at least two of the authors and analyzed on the basis of the identified categories and thematic dimensions. 
Table 2: Codes and Themes Used to Analyze the Papers

\begin{tabular}{|c|c|c|}
\hline Category & Description & Main Theme \\
\hline Accountability and responsibility & $\begin{array}{l}\text { accountability relations of different stakeholders related to an MSI (e.g., who is } \\
\text { accountable? why is accountability lacking?) }\end{array}$ & Input \\
\hline $\begin{array}{l}\text { Auditing and limits of auditing } \\
\text { and participatory auditing }\end{array}$ & $\begin{array}{l}\text { verification of auditing bodies; problems related to audits; unreliability of audits; } \\
\text { non-participation of actors in audits; need for and role of participation during local audits }\end{array}$ & Impact \\
\hline Branding & $\begin{array}{l}\text { discussions around how MSIs influence branding and marketing policies of adopters } \\
\text { (or other actors) }\end{array}$ & Impact \\
\hline $\begin{array}{l}\text { Competition, coordination, } \\
\text { and collaboration }\end{array}$ & $\begin{array}{l}\text { competition, coordination, and collaboration between different standards; industry vs. } \\
\text { NGO-driven standards; multiplicity of standards; commercial interests versus other } \\
\text { interests; trade-offs during standard development (e.g., between rigor and legitimacy) }\end{array}$ & Institutionalization \\
\hline Consumers & all aspects related to end consumers, including willingness to pay premiums & Impact \\
\hline $\begin{array}{l}\text { Decoupling MSI adoption and } \\
\text { improving compliance }\end{array}$ & $\begin{array}{l}\text { adopters decouple their commitment to a standard from actual practices; ways to make } \\
\text { adopters comply better with a standard }\end{array}$ & Impact \\
\hline Decoupling MSI development & accountability and inclusiveness of MSIs used as a ritual or for ceremonial reasons & Input \\
\hline Developing countries & north/south relations; role of smallholders and bigger plantations/farms in standard adoption & Impact + Institutionalization \\
\hline Experts, science, and knowledge & role of experts (academics, NGOs, consultants), science, and knowledge in standard setting & Input \\
\hline Gender & role of gender in both standard making and adoption & Input + Impact \\
\hline Government & $\begin{array}{l}\text { role of government in standard setting; public procurement; endorsement of standards; } \\
\text { inter-governmental support; links to hard law }\end{array}$ & Institutionalization + Impact \\
\hline Outcome and output & $\begin{array}{l}\text { output and outcome legitimacy; lack of impact of standard adoption (on different parties); } \\
\text { lack of enforcement of MSIs }\end{array}$ & Impact \\
\hline Inclusiveness and deliberation & $\begin{array}{l}\text { lack of participation of different groups (mostly smallholders, farmers); quality of deliberation } \\
\text { among stakeholders participating in standard }\end{array}$ & Input \\
\hline Input legitimacy & consequences of standard making (e.g., problems therein) for legitimacy of standard & Input \\
\hline
\end{tabular}


Table 2: continued

\begin{tabular}{|c|c|c|}
\hline Category & Description & Main Theme \\
\hline Diffusion & $\begin{array}{l}\text { diffusion of MSIs across different contexts (e.g., industries, geographies) and time; role of } \\
\text { institutional entrepreneurs in diffusion }\end{array}$ & Institutionalization \\
\hline Isomorphism & $\begin{array}{l}\text { MSIs modelled on one another or industry-driven standards modelled on MSIs; isomorphism } \\
\text { during standard adoption }\end{array}$ & Institutionalization \\
\hline Local context & $\begin{array}{l}\text { particularities of local context (history of a country, etc.) influence standard adoption and } \\
\text { impact; adaptation of standard to local context; influence of national institutions on } \\
\text { standard development (e.g., strength of unions, etc.) }\end{array}$ & Input + Institutionalization + Impact \\
\hline Neoliberalism and hegemony & $\begin{array}{l}\text { references made to neoliberalism, marketization, an d hegemonic forces during standard } \\
\text { development and adoption }\end{array}$ & Input + Impact \\
\hline Politics of standard development & $\begin{array}{l}\text { different players fighting (e.g., industry and NGOs); dominance/privileging of certain interests; } \\
\text { power asymmetries }\end{array}$ & Input \\
\hline Power in value chains & power differences in (global) supply chains during standard adoption; role of lead firms; sourcing & Impact \\
\hline
\end{tabular}




\section{BASIC CHARACTERISTICS OF MSI RESEARCH}

As Figure 1 illustrates, scholarly interest in MSIs has been growing in recent years. Fifty-seven percent of all the articles in our sample were published between 2012 and 2016. Figure 1 also shows that research activity with regard to both certification and principle-based MSIs has increased over the years. Research activity gained momentum especially after 2005. The fluctuation in the number of publications per year (e.g., between 2013 and 2014) can be explained by the publication of special issues, which contributed a number of articles to our dataset (e.g., Agriculture and Human Values, 2014, issue 3).

Figure 1 also shows that certification MSIs have attracted more scholarly attention than principle-based MSIs. Overall, our dataset contains 229 articles on certification MSIs, 54 articles on principle-based initiatives, and 10 articles that cover both types. Table 3 offers a more fine-grained analysis, showing that the majority of articles on principle-based MSIs are published in journals focusing on business ethics (e.g., Business Ethics Quarterly, Journal of Business Ethics, Business \& Society) or general management (e.g., Organization Studies). By contrast, research on certification MSIs can be found in broader social science multi-disciplinary journals (e.g., Agriculture and Human Values, World Development, Journal of Cleaner Production), although business ethics journals have also been relatively active in this field (e.g., Journal of Business Ethics, Business \& Society, Business Ethics Quarterly).

Table 3 also shows that most of the literature consists of qualitative studies, with conceptual and quantitative research lagging behind. This focus on qualitative data is understandable, given that many of the research topics currently addressed lend themselves to case study research (e.g., the politics underlying MSI development). Moreover, accessible quantitative data on MSIs is often lacking. For instance, compliance measures are hard to find when dealing with certification along global supply chains (Hale \& Opondo, 2005). Furthermore, it is challenging to isolate the effects of MSI participation through quantitative analyses; it is often unclear whether changes in organizational activities appear as a consequence of participating in an MSI or whether these activities would have also occurred without participation.

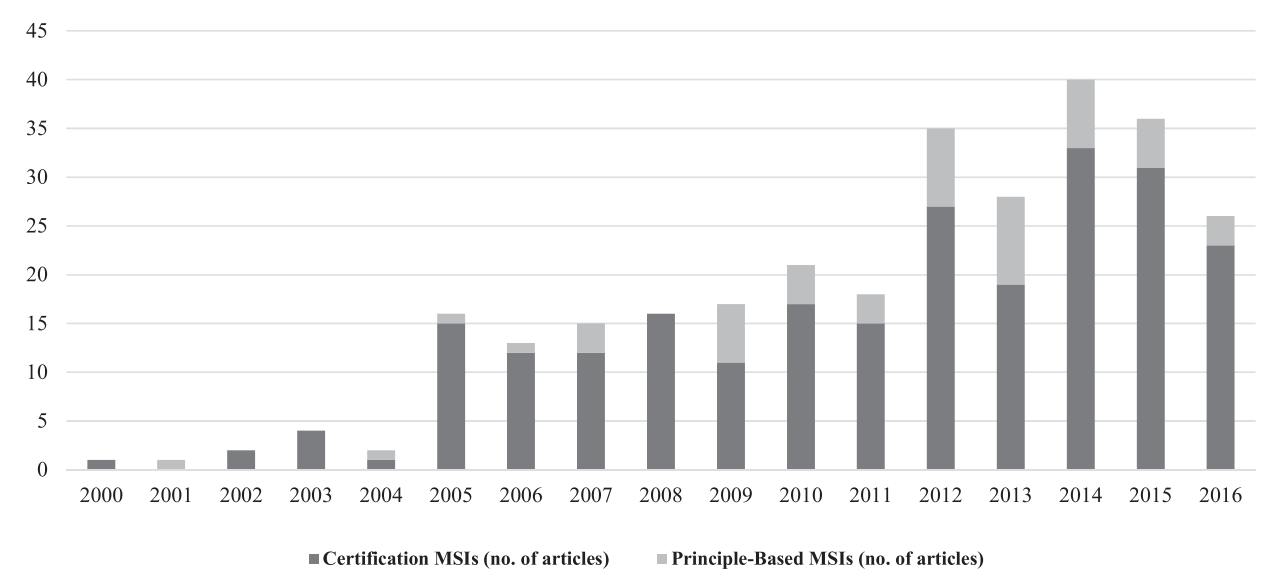

Figure 1: Number of Articles in Final Dataset/Year (2000-2016) 
Table 3: Academic Journals, Type of MSIs Analyzed, and Method Underlying Articles

\begin{tabular}{|c|c|c|c|c|c|c|c|c|c|}
\hline \multirow[b]{2}{*}{ Academic Journal } & \multirow[b]{2}{*}{ Disciplinary Focus } & \multirow[b]{2}{*}{$\begin{array}{l}\text { Overall No. } \\
\text { of Articles }\end{array}$} & \multicolumn{4}{|c|}{ Type of Analysis } & \multicolumn{3}{|c|}{ Type of MSI } \\
\hline & & & Conceptual & Qualitative & Quantitative & Mixed & Certification & $\begin{array}{l}\text { Principle- } \\
\text { based }\end{array}$ & Mixed \\
\hline Academy of Management Journal & Management & 2 & & 1 & 1 & & 1 & 1 & \\
\hline Academy of Management Review & Management & 2 & 2 & & & & 1 & & 1 \\
\hline Agriculture and Human Values & Food and Agriculture & 18 & 5 & 13 & & & 17 & & 1 \\
\hline Ambio & Environmental Studies & 2 & & 1 & 1 & & 2 & & \\
\hline Antipode & Geography & 2 & & 2 & & & 2 & & \\
\hline Business \& Society & Business Ethics & 13 & 5 & 5 & 3 & & 2 & 11 & \\
\hline Business Ethics Quarterly & Business Ethics & 4 & 3 & 1 & & & 2 & 2 & \\
\hline Ecological Economics & Economics & 4 & & 4 & & & 4 & & \\
\hline Ecology \& Society & Environmental Studies & 4 & & 3 & 1 & & 3 & 1 & \\
\hline Environment and Planning A & Geography & 2 & & 1 & 1 & & 1 & & 1 \\
\hline Environmental Politics & Political Science & 2 & & 2 & & & 2 & & \\
\hline Fisheries Research & Environmental Studies & 8 & 1 & 4 & 3 & & 7 & & 1 \\
\hline Forest Ecology and Management & Environmental Studies & 2 & & 1 & 1 & & 2 & & \\
\hline Forest Policy and Economics & Economics & 7 & & 4 & 3 & & 7 & & \\
\hline Geoforum & Geography & 9 & & 9 & & & 9 & & \\
\hline Global Environmental Change & Environmental Studies & 3 & 1 & 1 & 1 & & 3 & & \\
\hline Global Environmental Politics & Environmental Studies & 6 & 1 & 5 & & & 6 & & \\
\hline Global Governance & Political Science & 3 & 2 & 1 & & & 1 & 2 & \\
\hline Globalizations & Multidisciplinary & 3 & 3 & & & & 3 & & \\
\hline $\begin{array}{l}\text { International Food and Agribusiness } \\
\text { Management Review }\end{array}$ & Food and Agriculture & 4 & 1 & 3 & & & 4 & & \\
\hline International Forestry Review & Environmental Studies & 2 & & 1 & 1 & & 2 & & \\
\hline
\end{tabular}




\begin{tabular}{|c|c|c|c|c|c|c|c|c|c|}
\hline \multirow[b]{2}{*}{ Academic Journal } & \multirow[b]{2}{*}{ Disciplinary Focus } & \multirow[b]{2}{*}{$\begin{array}{c}\text { Overall No. } \\
\text { of Articles }\end{array}$} & \multicolumn{4}{|c|}{ Type of Analysis } & \multicolumn{3}{|c|}{ Type of MSI } \\
\hline & & & Conceptual & Qualitative & Quantitative & Mixed & Certification & $\begin{array}{c}\text { Principle- } \\
\text { based }\end{array}$ & Mixed \\
\hline Journal of Agrarian Change & Food and Agriculture & 2 & 1 & 1 & & & 2 & & \\
\hline Journal of Business Ethics & Business Ethics & 33 & 13 & 14 & 6 & & 9 & 22 & 2 \\
\hline Journal of Cleaner Production & Environmental Studies & 16 & & 11 & 5 & & 11 & 4 & 1 \\
\hline Journal of Economic Geography & Geography & 2 & & 2 & & & 2 & & \\
\hline Journal of Environment and Development & Development Studies & 5 & 1 & 3 & & 1 & 5 & & \\
\hline Journal of Forestry & Environmental Studies & 2 & & & 2 & & 2 & & \\
\hline Journal of Management Studies & Management & 4 & 2 & 1 & 1 & & 2 & 1 & 1 \\
\hline Journal of Rural Studies & Geography & 7 & & 7 & & & 7 & & \\
\hline Marine Policy & Political Science & 8 & 3 & 3 & 2 & & 8 & & \\
\hline New Political Economy & Political Science & 3 & & 2 & & 1 & 3 & & \\
\hline Organization & Management & 3 & 1 & 2 & & & 3 & & \\
\hline Organization Science & Management & 2 & & 2 & & & 1 & 1 & \\
\hline Organization Studies & Management & 3 & & 3 & & & 1 & 2 & \\
\hline Regulation \& Governance & Political Science & 10 & 2 & 5 & 3 & & 9 & 1 & \\
\hline Society and Natural Resources & Environmental Studies & 4 & & 3 & 1 & & 4 & & \\
\hline Sociologia Ruralis & Sociology & 2 & & & 2 & & 2 & & \\
\hline Sustainability & Multidisciplinary & 3 & & 1 & 2 & & 3 & & \\
\hline Sustainable Development & Multidisciplinary & 4 & & 2 & & 2 & 3 & 1 & \\
\hline Third World Quarterly & Development Studies & 4 & 1 & 2 & & 1 & 3 & 1 & \\
\hline World Development & Development Studies & 12 & 1 & 5 & 5 & 1 & 11 & 1 & \\
\hline Total & & 231 & 49 & 131 & 45 & 6 & 172 & 51 & 8 \\
\hline
\end{tabular}


Table 4 shows that most lead authors have a background in management, including business ethics (76), followed by environmental studies (55) and political science (51). This means that MSI research is truly multidisciplinary and is well established within the field of management. However, it also indicates that principle-based MSIs are not studied much outside of management studies. Our dataset also shows that while scholarship on MSIs has produced rich empirical insights, relatively few studies make explicit reference to theoretical perspectives in order to gain conceptual clarity on constructs and to create a theoretical narrative when interpreting results. Only 80 of the 293 surveyed studies make an explicit reference to theory (see Table 5). The majority of studies in our dataset are descriptive, i.e., they outline empirical results without interpreting the findings under the lenses of theory. Interestingly, a fair share of theoretical work is being conducted by management and business ethics scholars (30 out of 76 studies) and geography scholars (8 out of 19 studies).

\section{MAIN THEMES OF MSI RESEARCH}

Our analysis reveals three thematic areas in the MSI literature across disciplines: the input into creating and governing MSIs; the institutionalization processes; and the impact of MSIs (the 3Is). Despite some inevitable overlap, we maintain that they shed light on important aspects of MSIs. In this section, we introduce each theme, unpack its theoretical perspectives and research orientations, and identify one central research challenge that remains to be addressed from the perspective of business ethics research. We discuss differences between certification MSIs and principle-based MSIs whenever these are relevant. Table 6 summarizes our findings.

Table 4: Disciplinary Affiliations of Authors and Publications of Types of MSIs

\begin{tabular}{|c|c|c|c|c|}
\hline $\begin{array}{l}\text { Disciplinary Affiliation of } \\
\text { First Author }\end{array}$ & No. of Articles & Certification & Principle-Based & Both Types \\
\hline Agriculture & 4 & 4 & & \\
\hline Anthropology & 1 & 1 & & \\
\hline Development Studies & 7 & 6 & & 1 \\
\hline Economics & 6 & 5 & 1 & \\
\hline Environmental Studies & 55 & 50 & 2 & 3 \\
\hline Geography & 19 & 17 & & 2 \\
\hline History & 1 & 1 & & \\
\hline International Relations & 6 & 5 & 1 & \\
\hline Law & 4 & 4 & & \\
\hline Management (incl. Business Ethics) & 76 & 33 & 39 & 4 \\
\hline Multidisciplinary & 28 & 24 & 4 & \\
\hline Political Science & 51 & 47 & 4 & \\
\hline Sociology & 29 & 28 & 1 & \\
\hline Practitioner Articles & 6 & 4 & 2 & \\
\hline Total & 293 & 229 & 54 & 10 \\
\hline
\end{tabular}


Table 5: Disciplinary Affiliations of Authors and Theories Used in Articles

\begin{tabular}{|c|c|c|c|}
\hline $\begin{array}{l}\text { Disciplinary Affiliation } \\
\text { of First Author }\end{array}$ & $\begin{array}{l}\text { No. of } \\
\text { Articles }\end{array}$ & $\begin{array}{c}\text { Articles with } \\
\text { Reference to } \\
\text { Theory }\end{array}$ & Main Theories Used \\
\hline Agriculture & 4 & & \\
\hline Anthropology & 1 & 1 & justice theory \\
\hline Development Studies & 7 & 1 & convention theory \\
\hline Economics & 6 & & \\
\hline Environmental Science & 55 & 11 & global value chain theory \\
\hline Geography & 19 & 8 & $\begin{array}{l}\text { global value chain theory, } \\
\text { actor network theory }\end{array}$ \\
\hline History & 1 & & \\
\hline International Relations & 6 & 1 & neo-Gramscian theory \\
\hline Law & 4 & & \\
\hline Management (incl. Business Ethics) & 76 & 30 & institutional theory, stakeholder theory \\
\hline Multidisciplinary & 28 & 7 & global value chain theory \\
\hline Political Science & 51 & 10 & $\begin{array}{l}\text { institutional theory, global value } \\
\text { chain theory }\end{array}$ \\
\hline Sociology & 29 & 11 & institutional theory \\
\hline Practitioner Articles & 6 & & \\
\hline Total & 293 & 80 & \\
\hline
\end{tabular}

\section{Input into Creating and Governing MSIs}

Input is related to discussions about how MSIs are created and managed; it concerns the actors, decisions, processes, and practices that give rise to MSIs.

\section{Input Legitimacy}

An issue highlighted by a number of scholars from different disciplines is the input legitimacy of MSIs (e.g., Bernstein, 2011; Partzsch, 2011; Slager et al., 2012). Input legitimacy refers to the belief that "decisions are derived from the preferences of the population in a chain of accountability linking those governing to those governed" (Mayntz, 2010: 10). Focusing on input legitimacy involves assessing whether MSI governance is open to public scrutiny and stakeholder participation (Bäckstrand, 2006; García-López \& Arizpe, 2010). A number of articles delineate criteria for assessing the input legitimacy of MSIs (e.g., Mena \& Palazzo, 2012). One much-studied topic is how (a lack of) inclusiveness in standard-setting processes affects input legitimacy (e.g., Gilbert \& Rasche, 2007; Miller \& Bush, 2015; Pichler, 2013; Ponte, 2014), both in the context of certification and principle-based MSIs. Although many MSIs have set up governance structures that are supposed to enable equal participation of stakeholder groups, many studies show that these structures are seldom enacted in practice. Scholarly work in this area unveils how everyday problems, such as language barriers, access to financial resources, and lack of expert knowledge, challenge the inclusiveness of MSIs (Cheyns, 2014; Everett et al., 2008; 
Table 6: Overview of the "3Is" in the MSI Literature

\begin{tabular}{|c|c|c|c|c|c|}
\hline Theme & Subtheme & Illustrative References* & Key Findings & $\begin{array}{c}\text { Relevant Fields of } \\
\text { Study and Theoretical } \\
\text { Perspectives }\end{array}$ & $\begin{array}{c}\text { Research Challenges for MSI } \\
\text { Studies with a Business Ethics Focus }\end{array}$ \\
\hline \multirow[t]{2}{*}{ Input } & $\begin{array}{l}\text { Input } \\
\text { Legitimacy }\end{array}$ & $\begin{array}{l}\text { Bernstein (2011); Haack } \\
\text { et al. (2014); Mena and } \\
\text { Palazzo (2012); Ponte } \\
\text { and Cheyns (2013); } \\
\text { Schouten and } \\
\text { Glasbergen (2012); } \\
\text { Slager et al. (2012) }\end{array}$ & $\begin{array}{l}\text { - Higher levels of inclusiveness lead to } \\
\text { higher degrees of legitimacy. } \\
\text { - Although many MSIs have set up } \\
\text { governance structures that are supposed } \\
\text { to enable equal participation of } \\
\text { stakeholder groups, these structures are } \\
\text { seldom enacted in practice. }\end{array}$ & $\begin{array}{l}\text { - Governance studies } \\
\text { (private governance; } \\
\text { transnational } \\
\text { governance) } \\
\text { - Deliberative } \\
\text { Democracy } \\
\text { - Institutional theory } \\
\text { - Convention theory }\end{array}$ & \multirow{2}{*}{$\begin{array}{l}\text { - Challenge: Strong inward-looking } \\
\text { focus on single MSIs while discussing } \\
\text { the need to justify universally valid } \\
\text { norms via effective deliberation; } \\
\text { disregard of the larger context in } \\
\text { which deliberation happens } \\
\text { - Importance of Challenge: MSIs } \\
\text { are embedded into larger regulatory } \\
\text { systems and hence the deliberative } \\
\text { potential within a single MSI says } \\
\text { little about this initiative's ability to } \\
\text { justify its norms via deliberation }\end{array}$} \\
\hline & $\begin{array}{l}\text { Politics of } \\
\text { Standard } \\
\text { Development }\end{array}$ & $\begin{array}{l}\text { Bartley (2014); Elgert } \\
(2012) ; \text { Fransen (2012); } \\
\text { Hatanaka et al. (2012); } \\
\text { Levy et al. }(2010) ; \\
\text { Levy et al. }(2016)\end{array}$ & $\begin{array}{l}\text { - The politics inherent in setting up MSIs usually } \\
\text { happen backstage, with the front stage usually } \\
\text { showing a smoothly developed final product. } \\
\text { Coercive power plays an important role. } \\
\text { - Inter-organizational politics mainly play out } \\
\text { in certification-based MSIs, especially when } \\
\text { competing business-driven alternatives are } \\
\text { developed }\end{array}$ & $\begin{array}{l}\text { - Sociology (incl. } \\
\text { Goffmanian } \\
\text { dramaturgy) } \\
\text { - Political economy }\end{array}$ & \\
\hline
\end{tabular}


Table 6: continued

\begin{tabular}{|c|c|c|c|c|c|}
\hline Theme & Subtheme & Illustrative References* & Key Findings & $\begin{array}{c}\text { Relevant Fields of } \\
\text { Study and Theoretical } \\
\text { Perspectives }\end{array}$ & $\begin{array}{c}\text { Research Challenges for MSI } \\
\text { Studies with a Business Ethics Focus }\end{array}$ \\
\hline \multirow[t]{3}{*}{$\begin{array}{l}\text { Institutio- } \\
\text { nalization }\end{array}$} & $\begin{array}{l}\text { Motivation to } \\
\text { Adopt }\end{array}$ & $\begin{array}{l}\text { Cashore (2002); Gilbert } \\
\text { and Rasche (2010); } \\
\text { Nesadurai (2013); Ponte } \\
\text { (2012); Williams (2004) }\end{array}$ & $\begin{array}{l}\text { - Market actors are interested in joining } \\
\text { MSIs because of reputational benefits, } \\
\text { meeting consumer demand, investor } \\
\text { pressure, and risk management motives. } \\
\text { - Consumer-related arguments are often } \\
\text { used to adopt certification MSIs. } \\
\text { - Arguments based on reputational benefits } \\
\text { or improved investor links are often used } \\
\text { to adopt principle-based initiatives. }\end{array}$ & $\begin{array}{l}\text { - Collective action theory } \\
\text { - Stakeholder theory } \\
\text { - Global Value Chain } \\
\text { theory }\end{array}$ & \\
\hline & Diffusion & $\begin{array}{l}\text { Etzion and Ferraro } \\
\text { (2010), Gulbrandsen } \\
\text { (2008), Pattberg (2005); } \\
\text { Rasche (2012) }\end{array}$ & $\begin{array}{l}\text { - Institutionalization is driven by the } \\
\text { legitimacy of institutional design. } \\
\text { - Mimicry of design elements can be a } \\
\text { strategy to diffuse a standard. } \\
\text { - Key challenge during diffusion is to } \\
\text { adequately align the governance of MSIs } \\
\text { with the interplay of abstract global rules } \\
\text { and contextualized local practices. This } \\
\text { requires adaptable governance structures. }\end{array}$ & $\begin{array}{l}\text { - Institutional theory } \\
\text { - Experimentalist } \\
\text { governance } \\
\text { - Actor-network theory } \\
\text { - Socio-technical } \\
\text { systems thinking }\end{array}$ & \multirow{2}{*}{$\begin{array}{l}\text { - Challenge: Much of the literature } \\
\text { focuses on market-based motivations } \\
\text { and hence highlights utilitarian } \\
\text { reasoning - reflections on other types } \\
\text { of motivations (e.g., deontological } \\
\text { reasoning) are missing } \\
\text { - Importance of Challenge: MSIs are } \\
\text { adopted by a wide variety of firms, } \\
\text { including mission driven organizations } \\
\text { which do not necessarily focus } \\
\text { exclusively on utilitarian reasoning }\end{array}$} \\
\hline & Coexistence & $\begin{array}{l}\text { Fransen (2012); Fransen } \\
\text { and Burgoon (2014); } \\
\text { Manning et al., (2012); }\end{array}$ & $\begin{array}{l}\text { - MSIs coexist because standards-setters } \\
\text { can differentiate themselves despite the } \\
\text { existence of similarities. }\end{array}$ & $\begin{array}{l}\text { - Institutional theory } \\
\text { - Experimentalist } \\
\text { governance }\end{array}$ & \\
\hline
\end{tabular}

- In many cases, coexistence of (certification-

(2014); Reinecke et al. based) MSIs is problematic as it is likely to

(2012); Riisgaard (2011), cause a regulatory "race to the bottom" and undermines institutionalization processes by fragmenting markets for sustainable products. - In other cases, coexistence can lead to a

"race to the top" in the longer term.

- Mutual adjustment is suggested as a way to deal with coexistence. 
Table 6: continued

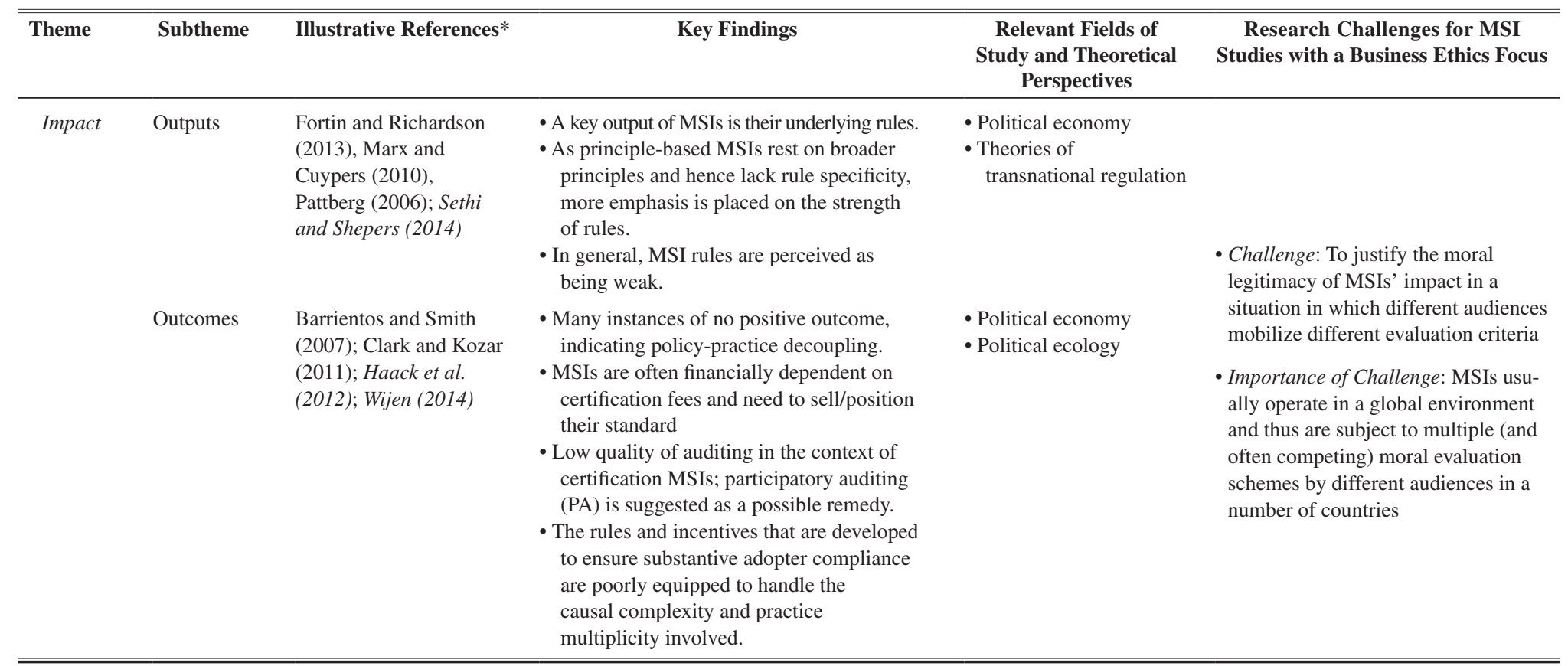

* Papers from general management and business ethics journals are displayed in italics. 
Schouten et al., 2012) and/or how actors choose not to participate for ideological reasons (Elgert, 2012).

Despite this attention for elements of legitimacy, surprisingly little work in our dataset focused on legitimacy theory (Suchman, 1995; Suddaby et al., 2017). This is peculiar, since legitimacy theory would allow scholars to make more fine-grained distinctions between different types of input legitimacy among MSIs. While articles focusing on deliberative theories often have an implicit focus on value-oriented moral legitimacy, the roles of pragmatic legitimacy and cognitive legitimacy remain insufficiently studied within the literature. Furthermore, legitimacy is mostly treated in a quite static manner in the literature; only a few studies focus on how an initial process of ascribing legitimacy to MSIs is followed by social judgment formation that further affects input legitimacy (for an exception, see Haack et al., 2014).

The Politics of Standards Development

Input is also shaped by how standard-development processes embody politics, and how struggles over power and representation are conceptualized (e.g., Gale, 2014; Klooster, 2010; Levy et al., 2010; Nicholls \& Huybrechts, 2016). Two strands of literature have tackled these questions.

A first group has focused on the politics inherent in setting up MSIs (e.g., Bartley, 2014; Büthe, 2010; Levy et al., 2010; Ponte, 2008; Verbruggen, 2013). Hatanaka et al. (2012), for example, have shown how the Biotechnology Industry Association undermined the creation of a sustainable agriculture MSI by contesting the suggested procedures and questioning the sources of expert knowledge. Based on Goffman (1959), they argue that the politics of standards development mostly happen backstage where the political struggles are carried out, while the front stage shows a smoothly developed final product. Although power is a key theoretical concept within this line of work, the literature acknowledges this only implicitly. Interestingly, power is mostly ascribed to actors possessing valuable resources or operating in a favorable position (e.g., lead firms in global value chains; Elgert, 2012). Other faces of power, such as manipulation (e.g., shaping anticipated results) or domination (e.g., manufacturing consent), are not discussed in the literature.

A second group has approached the politics of standards development from an interorganizational perspective. This angle has almost exclusively been applied to certification initiatives. Relevant studies have examined how the development of MSIs has been challenged by the creation of business-driven initiatives (e.g., Fransen, 2012; Kolk \& van Tulder, 2002; Manning et al., 2012). Fransen (2012) shows that some business-driven initiatives have incorporated notions of multi-stakeholder governance without changing their official institutional structures, while others have made changes to their governance structure but without fundamentally altering their business-driven nature. Recent analyses extend this perspective by investigating how entire value regimes emerge and how interactions between MSIs and businesses take place within a Gramscian framework of passive revolution, i.e., through the interplay between revolutioninducing transformations and progressive restoration of the status quo (e.g., Levy et al., 2016). 
Key Research Challenge: Norm Justification via Deliberative Systems

Few scholars have discussed input-related topics with an explicit focus on business ethics. The three publications in our dataset that explicitly do so focus on the question of norm justification (Gilbert \& Rasche, 2007; Mena \& Palazzo, 2012; Schouten \& Glasbergen, 2012). Norm justification seems important, as most certification and principle-based MSIs are designed as global initiatives and hence promote universal norms. Yet, particularly MSIs that promote universal norms need to justify a common moral basis, which serves as a ground for gaining cross-cultural acceptance. All three studies emphasized the need to understand norm justification as a deliberative process in which, ideally, all affected stakeholders are included.

Such deliberative perspectives hold a lot of potential, mostly because they acknowledge that MSIs' normative foundation "is socially constructed by giving and considering reasons" (Palazzo \& Scherer, 2006: 73). However, future research needs to extend these discussions by acknowledging that MSIs' norms cannot be justified by treating relevant initiatives as isolated entities. Current research looks at deliberation processes within MSIs. For instance, Gilbert \& Rasche (2007) focus on the communicative rationality surrounding SA 8000, while Mena \& Palazzo (2012) study the deliberative structure underlying the FSC. While such analyses provide a helpful assessment of the deliberative potential of MSIs' governance structures, they neglect that the possibilities of effective deliberation are also shaped by the context in which an initiative is embedded. As MSIs are usually part of larger governance systems in which state and non-state actors interact in various ways (Auld, 2014), it is critical to acknowledge the broader sociopolitical context in which deliberation happens. A certain MSI may show high degrees of deliberative potential because it includes a number of different stakeholders into its governance structure. However, the same MSI may also avoid cooperation with other initiatives or even governmental bodies and thereby undercut the possibilities for deliberation on a larger scale (Moog et al., 2015). Future scholarly work in business ethics should therefore adopt a broader systems-based deliberative perspective when discussing norm justification.

\section{The Institutionalization of MSIs}

Scholarly work in this area focuses on how MSIs, once created, are turned into stable institutions. This literature examines three main aspects: (1) firms' motivation to adopt MSIs, (2) diffusion processes, and (3) the coexistence of MSIs.

\section{Motivation to Adopt}

In theorizing firms' motivation to adopt MSIs, several scholars have suggested a market-based approach, arguing that market actors themselves, especially consumer-oriented firms, are interested in adoption (e.g., Cashore, 2002; Miles \& Munilla, 2004; Nesadurai, 2013). This approach focuses on reputational benefits (Nesadurai, 2013) and increasing consumer demand (Johansson, 2014). While consumer-related arguments are often raised in relation to certification MSIs, the motivation to join principle-based initiatives is usually discussed in the context of reputational benefits and improved links to investors (Amer, 2018). ${ }^{4}$ The market-based approach highlights 
the economic advantages of MSIs, assumes that collective action is needed to fully reap benefits (e.g., Cashore et al., 2005; Klooster, 2006), and acknowledges that firms join MSIs to find a solution to a collective action problem-especially when their reputations are interdependent and when there may be negative legitimacy spillover effects. Few scholars have challenged the dominant market-based approach to explain MSI adoption. One notable exception is Bartley's (2007) study, which outlines a political-institutional approach that views MSIs as instances of institutional entrepreneurship that are embedded into a larger system of strategic negotiations among a variety of state and non-state actors. Firms join MSIs as they view them as "compromised" forms of private regulation.

\section{Diffusion Processes}

Diffusion processes of certification MSIs are mostly discussed in the context of "mainstreaming" - i.e., the increase in the volume and number of certified products and/or producers (e.g., Klooster, 2010). It involves the adoption of MSIs by largescale buyers and the certification of big suppliers (Fortin, 2013; Ponte, 2012). Mainstreaming has been conceptualized as a double-edged sword: while it drives market creation and may change the practices of powerful actors (Pattberg, 2005), it can also negatively affect MSI governance structures as large actors capture the multi-stakeholder process (Llach et al., 2015; Ponte, 2014).

More theoretical work in this field has focused on how governance processes support the diffusion of MSIs. The underlying question is how to align MSI governance with the interplay of rather abstract global rules and more contextualized local practices. A number of scholars have highlighted the need for adaptable governance structures (e.g., Auld et al., 2015; Rasche, 2012), often framed as "experimentalist governance." Such an approach combines broad principles with a local participatory architecture for testing their relevance (Overdevest \& Zeitlin, 2014). Rasche (2012), for example, focuses on experimentalist governance through coupled networks and highlights the strength of ties between participants in a multilevel governance system. He argues that looser ties among local networks allow for local experimentation. Experimentalist governance has also been studied through actor network theory (e.g., Bear \& Eden, 2008; Eden, 2009; Kohne, 2014). For example, Eden (2009) explores how the role of boundary objects, such as the FSC tick-tree symbol, can help to customize a global standard and give it meaning in a social context, thereby supporting diffusion processes.

Diffusion processes have also been examined through institutional theory. Several authors stress the importance of isomorphism, showing that institutionalization is driven by the legitimacy of institutional designs and that mimicry of design elements impacts diffusion (e.g., Gulbrandsen, 2008; Manning \& von Hagen, 2010). Other studies argue that the resulting organizational homogeneity has its limits. For example, while business-driven forest certification schemes mimicked a number of the characteristics of the FSC, they carefully filtered out those aspects they did not like (Gulbrandsen, 2008). Isomorphism is mostly discussed in relation to certification MSIs, while work on institutional entrepreneurship has a stronger focus on principle-based initiatives. Etzion and Ferraro's (2010: 1092) work is a case in point. 
They theorize the dual role of analogies in institutionalizing the GRI, suggesting that analogies initially operate "as a normative mechanism" because "the emphasis on similarity to existing institutions stresses conformity and promotes legitimacy." Later on, these analogies can give rise to institutional innovation because they highlight differences and aberrations, creating room for institutional change (see also Levy et al., 2010).

\section{Coexistence}

A rapid growth of different certification MSIs has been observed in several sectors, including coffee (Manning et al., 2012), apparel (Fransen \& Burgoon, 2014), and the cut-flower industry (Riisgaard, 2011). The debate on coexistence is limited to certification MSIs and often draws on insights from institutional theory, as standard multiplicity is discussed vis-à-vis institutionalization processes (e.g., Fransen \& Burgoon, 2014; Prado, 2013). Some scholars view multiplicity as an obstacle to institutionalization, since the coexistence of similar initiatives makes it harder to secure sufficient suppliers who are able to meet certification requirements (e.g., Ponte, 2014). Others point out that sustainability issues face higher degrees of ambiguity (compared to technical issues) and that the resulting interpretive flexibility makes it harder to agree on a common baseline (Bush et al., 2013; Clark \& Kozar, 2011). Reinecke, Manning, and von Hagen (2012) argue that MSIs coexist because standards-setters are able to differentiate themselves despite the existence of similarities - for instance, by stressing distinctive features of sustainability, by targeting different producer groups, and by offering different levels of stringency.

A majority of contributions view coexistence as a problem in that increased competition may cause a regulatory race to the bottom, thus undermining institutionalization processes as markets for sustainable products become scattered amongst a number of niche players (Bloomfield, 2012; Egels-Zandén \& Wahlqvist, 2007; Fortin \& Richardson, 2013; Fransen, 2012; O'Rourke, 2006; Ponte, 2012). Some of these analyses focus on power and hegemony, mostly to show that competition among MSIs leads to a situation in which initiatives are pressured to conform to the basic conditions of the neoliberal global economy (e.g., Bloomfield, 2012). Others, however, have suggested a moral pull of "gold standard" MSIs, leading to a race to the top (e.g., Overdevest \& Zeitlin, 2014). Business-driven standards and international organizations then may act in ways that incorporate potentially counterhegemonic ideas, and/or a community of MSIs with shared interests can increase the potential for learning and coevolution (e.g., Manning et al., 2012).

\section{Key Research Challenge: Beyond Utilitarian Motivations to Adopt MSIs}

Surprisingly few contributions in our dataset challenge the assumption that firms join MSIs for market-based motivations - translating into higher long-term financial returns (for an exception see Williams, 2004). For business ethicists this neglect of alternative ways of reasoning shows the dominance of utilitarianism. In this worldview, MSIs are a means to an end. People and the environment are to be protected through sustainable business practices, but they hold no intrinsic value in themselves 
in corporate decision-making processes. While such utilitarian reasoning can explain why some firms join MSIs, and utilitarian thinking certainly reflects a valid moral point of view (Singer, 1993), it would be misleading to claim that the motivation of all adopters can be limited to such instrumental motives.

A utilitarian perspective overlooks that some firms also value the benefits that MSIs create as ends in themselves, regardless of their usefulness to create any utilitarian benefits. For instance, the underlying utilitarian logic does not capture the interests of mission-driven firms in the fair-trade segment very well. Some of these firms are organized in the World Fair Trade Organization (WFTO), which puts alternative norms such as "fairness" and "partnership" at its core, and thus tries to distance itself from purely commercial buyers (Raynolds, 2009). Although it would be naïve to argue that instrumental motives are completely absent in mission-driven firms, it is also clear that the adoption of MSIs by certain organizations cannot be sufficiently explained without acknowledging other ethical perspectives. In order to explain and better theorize these cases it is important to explore-conceptually as well as empirically — other ways in which actors ethically justify the decision to join a MSI.

\section{Impact of MSIS}

The scholarly debate on the impact of MSIs has been mainly shaped by two central topics: (1) impact measured in terms of outputs (e.g., number of certified facilities, area, or quantity certified); and (2) impact measured in terms of outcomes (e.g., improvements in working/production conditions and/or the environment). ${ }^{5}$

\section{Outputs}

Many studies examine outputs of MSIs at face value (number of certified actors, quantity of product, or area certified; e.g., Espinoza, Buehlmann, \& Smith, 2012; Miteva, Loucks, \& Pattanayak, 2015). Yet, merely reporting on outputs does not offer much of an insight on how this output came about or how it could be explained. For instance, boasting the number of MSC fishery certifications does not necessarily imply that these fisheries are recovering in practice (Ponte, 2012).

A number of studies therefore look at how relevant outputs can be explained. These studies acknowledge that output is linked to the rules that MSIs promote (e.g., rules that specify what exactly is to be certified), and that these rules can have different consequences for different groups of actors. Studies by Pichler (2013) and Ponte and Cheyns (2013), for example, have shown how the RSPO's certification rules favor larger estates that can achieve economies of scale, while small-scale farmers often have problems obtaining certification. Other authors focus on the implications of unspecific rules, especially in relation to principle-based MSIs (Haack \& Scherer, 2014; Sethi \& Schepers, 2014), and on how their alignment with Western values limits their uptake. Pattberg (2006) argues that the perception of what counts as "good forest management" is mostly based on Western scientific standards (see also Hatanaka, 2010; Ponte, 2012) and that this has implications for which kinds of actors can comply more easily with relevant MSIs. A few authors discuss this Western embeddedness through the lens of Gramscian theory (Moog et al., 2015; Levy et al., 2010) and 
thereby conceptualize MSIs as hegemonic forces that advance the neoliberal political agenda. These studies reach beyond an analysis of the hegemonic forces at play during standards development (see above), highlighting ways in which MSIs' output can be undercut by political-economic constraints that shape the relevant market environment.

\section{Outcomes}

Studies with a focus on outcomes for the final beneficiaries of MSIs often lack clear reference to theoretical perspectives (for an exception, see Haack et al., 2012) and instead focus on presenting empirical results. Despite a number of methodological challenges (e.g., cross-country outcome data on a portfolio of indicators is seldom available; Clark \& Kozar, 2011), the idea that MSIs create selective or only marginal positive outcomes for final beneficiaries is firmly embedded in the literature (e.g., Gulbrandsen, 2009; McCarthy, 2012; Pattberg, 2006; Ponte, 2012). Some studies argue that MSIs create no positive outcomes at all, and thus indicate policy-practice decoupling. Such decoupling is observed both in certification MSIs (Barrientos \& Smith, 2007; Hatanaka, 2010; Marx, 2008; Schwartz \& Tilling, 2009; Selfa et al., 2014) and in principle-based MSIs (Knudsen, 2011; Vigneau et al., 2015). Wijen (2014) has expanded this debate to include the role of means-ends decoupling. He argues that while policy-practice decoupling assumes that adopters do not implement MSIs despite formally embracing them, means-ends decoupling shows that adopters may be compliant with formal policies but fail to achieve the goals intended by MSIs. In highly opaque fields, it is less likely that initiatives that follow a narrow compliance orientation will achieve their intended goals. This points towards a trade-off (Wijen, 2014): while rigid rules may compromise MSIs' ability to achieve their goals (means-ends decoupling), more flexible rules may increase the risk of merely symbolic adoption (policy-practice decoupling). Regardless of its nature, most research examines decoupling as a static phenomenon.

A number of studies link poor outcomes to certification MSIs often being financially dependent on certification fees and the resulting need to sell/position an initiative. Such a situation can create incentives to lower standards in order to attract clients (Fortin \& Richardson, 2013; O’Rourke, 2006; Ponte, 2012). Other studies have linked poor outcomes to low-quality auditing, for instance, when audits fail to incorporate local workers (Hale \& Opondo, 2005) or when there are vested business interests (Gulbrandsen, 2009; Pattberg, 2006; Schepers, 2010). These poor outcomes then may be the result of several stakeholders not accepting the espoused norms or the way they have been created. ${ }^{6}$ Participatory auditing is suggested as a possible remedy (Hale \& Opondo, 2005; Nelson \& Tallontire, 2014; O'Rourke, 2006; Riisgaard, 2011). The rationale for participatory auditing rests on a theoretical assumption embedded in deliberative democracy: that higher levels of stakeholder inclusiveness (e.g., involving local NGOs or unions in auditing processes) will yield more legitimate results.

\section{Key Research Challenge: Morally Justifying MSI Impact}

While our review shows that research has made advances to understand the output and outcomes that MSIs have produced so far, relevant studies have suffered from 
at least two central shortcomings, both of which are of relevance to business ethics scholars. First, the impact of MSIs is often treated as an objective fact-that is, something that just needs to be measured (see, e.g., Miteva et al., 2015; Nebel et al., 2005). Research tends to neglect that MSIs' impact depends on when and where the judgment is made, how impact is measured, and most of all on who is judging. Second, and relatedly, for an impact assessment to have any influence it needs to be viewed as morally legitimate by those who evaluate it. Prior research emphasized that such moral legitimacy results from a fit between the evaluated entity and the societal-level moral schemes around it (Ruef \& Scott, 1998). For instance, the impact of a MSI targeting climate change would be evaluated based on its alignment with the socially constructed value system in place.

However, such an understanding of moral legitimacy creates problems for MSIs, which usually operate on a global level and hence are subject to multiple (and often competing) schemes of moral evaluation by different audiences. It is therefore not surprising that NGOs, governments, and businesses can view the impact of MSIs differently. For instance, the impact created by the UNGC remains contested and is evaluated in different ways by NGOs, businesses, and the UN itself (Rasche, 2009). Such a situation creates high degrees of uncertainty, as the criteria by which the moral legitimacy of impact should be judged remain contested (see also Cheyns, 2014). Future research within business ethics needs to clarify how different actors mobilize different moral legitimacy criteria to justify MSIs' impact, and how disputes between actors with different criteria can be resolved. Such research would be critical to better understand why the normative basis for judging the legitimacy of MSIs' impact differs between actor groups and what can be done about it.

\section{ADVANCING MSI RESEARCH THROUGH BUSINESS ETHICS}

The 3Is serve as a framework for organizing and categorizing the diverse sets of studies on MSIs across academic disciplines. While we show that business ethicists are active in this scholarly debate, only selected insights from business ethics (mostly related to deliberative reasoning and stakeholder theory) have found their way into the broader scholarship. In this section, we identify how the challenges for future research at the MSI-business ethics interface, which we identified in the preceding section, can be tackled through theoretical engagement with selected parts of the business ethics literature (see summary in Table 7). We continue to use the 3Is as an overarching framework for our discussion. We therefore discuss three research challenges within the 3Is and one research challenge across the 3Is.

In doing so, we suggest two distinct ways to create theoretical advances. Our discussion of the research challenge related to input demonstrates the relevance of applying current theoretical approaches (i.e., those already used by business ethicists who study MSIs) to new research questions. By contrast, our discussion of the research challenges related to institutionalization, impact, and the challenge that cuts across the 3Is highlights that new theoretical approaches (i.e., those currently not used by business ethicists who study MSIs) can also be applied to new research questions. 


\section{Table 7: Future Research Directions on MSIs in Business Ethics}

\begin{tabular}{|c|c|c|c|c|}
\hline \multirow[b]{2}{*}{ Topic } & \multicolumn{3}{|c|}{ Within 3Is } & \multirow{2}{*}{$\begin{array}{c}\text { Across 3Is } \\
\text { Ethical Leadership within MSIs }\end{array}$} \\
\hline & $\begin{array}{l}\text { Norm Justification via } \\
\text { Deliberative Systems }\end{array}$ & $\begin{array}{c}\text { Beyond Utilitarian } \\
\text { Motivations to Adopt MSIs }\end{array}$ & Morally Justifying MSI Impact & \\
\hline Related 3I Theme & Input & Institutionalization & Impact & Across 3Is \\
\hline $\begin{array}{l}\text { Research Challenge } \\
\quad \text { Resulting from Review }\end{array}$ & $\begin{array}{l}\text { Inward-looking focus on single } \\
\text { MSIs while discussing the } \\
\text { need to justify universally } \\
\text { valid norms via deliberation }\end{array}$ & $\begin{array}{l}\text { Strong focus on utilitarian } \\
\text { arguments when justifying } \\
\text { adoption of MSIs by firms }\end{array}$ & $\begin{array}{l}\text { Too much emphasis on objective } \\
\text { criteria for assessing impact; } \\
\text { disregard of socially } \\
\text { constructed nature }\end{array}$ & $\begin{array}{l}\text { Limited attention for how } \\
\text { individual leaders interact } \\
\text { with input, institutionalization, } \\
\text { and impact }\end{array}$ \\
\hline Exemplary & $\begin{array}{l}\text { How are deliberative systems } \\
\text { around MSIs structured? }\end{array}$ & $\begin{array}{l}\text { How can we justify the } \\
\text { adoption of MSIs when } \\
\text { moving beyond utilitarian } \\
\text { thinking? }\end{array}$ & $\begin{array}{l}\text { How do different actors mobilize } \\
\text { different moral legitimacy } \\
\text { criteria to justify MSIs' impact? }\end{array}$ & $\begin{array}{l}\text { How do the politics related to } \\
\text { the development of a joint } \\
\text { initiative (input) interact } \\
\text { with leaders' ability to create } \\
\text { norm-defining discourses? }\end{array}$ \\
\hline Research Questions & $\begin{array}{l}\text { How do MSIs' deliberative } \\
\text { system influence the } \\
\text { justification of their norms? }\end{array}$ & $\begin{array}{l}\text { Do firms adopt MSIs as } \\
\text { macrosocial contracts because } \\
\text { they are perceived as fair by } \\
\text { relevant stakeholders? }\end{array}$ & $\begin{array}{l}\text { How can disputes over MSIs' } \\
\text { impact between actors with } \\
\text { different legitimacy criteria } \\
\text { be resolved? }\end{array}$ & $\begin{array}{l}\text { Will newly emerging outputs } \\
\text { and outcomes (impact) still be } \\
\text { viewed as morally acceptable } \\
\text { by stakeholders? }\end{array}$ \\
\hline Relevance of Future Research & $\begin{array}{l}\text { Neglect that the possibilities } \\
\text { of effective deliberation are } \\
\text { shaped by the broader system } \\
\text { of actors around MSIs }\end{array}$ & $\begin{array}{l}\text { Not all firms have utilitarian } \\
\text { motives when adopting MSIs } \\
\text { (e.g., mission-driven firms) }\end{array}$ & $\begin{array}{l}\text { MSIs are evaluated by different } \\
\text { audiences which mobilize } \\
\text { different moral frames to } \\
\text { judging impact }\end{array}$ & $\begin{array}{l}\text { Need to show interaction } \\
\text { effects between the } 3 \text { Is } \\
\text { (including trade-offs) }\end{array}$ \\
\hline Theoretical Perspective(s) & Deliberative systems thinking & Deontological ethics ISCT & Economies of worth & Ethical leadership \\
\hline Related Scholarly Work* & $\begin{array}{l}\text { Gilbert and Rasche (2007); } \\
\text { Mena and Palazzo (2012) }\end{array}$ & $\begin{array}{l}\text { Raynolds (2009); Bowie (1998); } \\
\text { Donaldson and Dunfee (1994) }\end{array}$ & $\begin{array}{l}\text { Reinecke et al. (2017); } \\
\text { Cheyns (2014) }\end{array}$ & $\begin{array}{l}\text { Bieri and Boli (2011); Patzer } \\
\text { et al. (2018) }\end{array}$ \\
\hline
\end{tabular}

* These references are based on our dataset and on additional searches for illustrative examples. 


\section{Business Ethics Research Challenges Within the 3Is}

Input: Norm Justification via Deliberative Systems

We identified the lack of contextual embeddedness of deliberative norm justification processes as a research challenge for business ethics scholars studying MSIs' input (see above). Studies that assess the deliberative potential of MSIs (and thus their ability to communicatively justify the underlying norms) cannot treat relevant initiatives in isolation; they need to acknowledge the broader system in which deliberative processes unfold. In order to theoretically frame such an extended perspective on deliberation, we suggest considering recent insights from deliberative democracy theory (Elstub \& Mclaverty, 2014; Mansbridge et al., 2012). As deliberative democracy reflects a theory perspective, which is already used by business ethics scholars to study MSIs (see, e.g., Mena \& Palazzo, 2012), our discussion shows how this theoretical framing can be fruitfully applied to new research questions and also how the theoretical approach itself can be expanded by considering recent insights from deliberative thinking.

The point of departure for a deliberative systems view on MSIs is to acknowledge that norms are not just rationalized by reaching high degrees of communicative rationality within an MSI, but also by focusing "on whole systems, of which any single deliberative forum is just a part" (Dryzek, 2010: 7), thus reaching beyond individual initiatives to look at "the broader political-economic context" (Moog et al., 2015: 488). A systemic view on deliberation would thus acknowledge that MSIs are embedded in a system consisting of other (competing) MSIs, business-driven initiatives, state-based regulatory systems, and a number of other actors (e.g., mass media, NGOs, trade unions, business associations). While some of these actors play an important role when judging whether a MSI meets the standards of deliberative democracy, a deliberative systems perspective would look beyond individual organizations to see whether the norms of deliberation exist across the system as a whole. This implies analyzing the multiple formal and informal ways in which MSIs and other actors interact, and how this network of linkages influences the communicative processes that underlie norm justification. While single MSIs may be able to achieve authentic deliberation within their own boundaries, they may look less beneficial in a wider systems perspective, because they may displace other deliberative institutions (e.g., social movements).

The opposite can also apply. For instance, at first glance, the UNGC seems to suffer from low levels of deliberation and inclusiveness in terms of its internal governance structure (Sethi \& Schepers, 2014). However, on a systems level, the Compact has significantly shaped the discussion of universal ethical norms in the media and thereby further opened the debate around corporate sustainability (Det Norske Veritas \& UN Global Compact, 2015). The media, which is typically excluded from deliberative analyses (Mansbridge et al., 2012), plays an important epistemic role, as it connects different parts of the underlying system. A systemic approach would not weigh the UNGC's low levels of "internal" inclusiveness against its higher levels of "systemic" connectivity in the sense that one could compensate for the other. Rather, the goal is to judge the deliberative capacity of the system as a whole. 
Future scholarly work needs to outline the structure and functions of deliberative systems surrounding MSIs, show how such systems influence the justification of underlying norms, and also explore the deficiencies of such an approach.

\section{Institutionalization: Beyond Utilitarian Motivations to Adopt MSIs}

Another key challenge identified in our review is the dominance of utilitarian reasoning (in the form of market-based reasoning) when discussing why firms would join MSIs. Business ethics scholars can address this shortcoming by introducing two alternative theoretical perspectives into the MSI discourse: (1) deontological reasoning and (2) integrative social contracts theory. Focusing on these two perspectives does not imply that other business ethics theories are less relevant. For instance, normative stakeholder theory could also be used to further tease out the limits of utilitarian reasoning. Also, we should not forget that utilitarian reasoning itself brings a particular moral dimension of MSIs to the forefront (Singer, 1993). Acknowledging that utilitarian reasoning itself provides a moral foundation is therefore important to discuss MSIs from a variety of ethical perspectives.

Applying deontological ethics (Bradley, 2006; Reynolds \& Bowie, 2004) to institutionalization processes would put emphasis on adopting MSIs because it is "the right thing to do." Such reasoning would emphasize that MSIs should be joined by companies because they have a moral duty to respect the rights of others (e.g., other humans, ecosystems, animals; Starik 1995; Whiteman et al., 2013). Such duty-based reasoning could rest, among others things, on the universalizability approach-whether firms' decision to adopt a MSI can be understood as a universal law. More specifically, future research could discuss firms' decision to adopt MSIs as a market transaction from the perspective of a Kantian theory of capitalism (Bowie, 1998). This would assess the moral worth of this transaction by reflecting on whether it could be treated as a universal law (Kant, 1785 [1990]). For instance, joining an MSI based on a false promise would not be seen as morally permissible - if every firm made false promises, nobody would believe them. Future scholarly work reaching out in this direction could focus on the intention of corporate decision makers when adopting a MSI. Such research would reveal a more comprehensive view of MSI adoption.

While deontological reasoning can provide general guidance on how to frame alternative motivations to adopt MSIs, its universal reasoning does not acknowledge the context-specific nature of business situations in which relevant initiatives are embedded. Therefore, we suggest a second way to conceptualize alternative motivations for adoption: integrative social contracts theory (ISCT). Following the contractarianism stream in moral philosophy (Rawls, 1971), ISCT rests on a twotiered conception of social contracts (Donaldson \& Dunfee, 1994): (1) a macrosocial contract that defines the generally valid normative ground rules for decisions that govern economic morality, and (2) a microsocial contract among members of communities that specifies and adapts the generally valid normative ground rules. This two-tiered conception of social contracts considers that one-size-fits-all solutions to business morality are not appropriate, and that local actors have a certain moral free space to further specify and adapt the relevant norms specified through the macrosocial contract. 
ISCT seems particularly relevant to the discussion of MSI adoption for two reasons. First, it deals with ethical decision-making in the context of value pluralism and the existence of different cultural backgrounds (Gilbert \& Behnam, 2009), both of which are relevant to the study of MSIs. Second, some MSIs (such as the FSC) are structured along a two-tiered system consisting of a set of universally valid norms (macro) that are specified through local networks (micro) (Rasche, 2012). ISCT would theorize MSIs' underlying norms as being part and parcel of a macrosocial contract. Firms would adopt MSIs because the underlying macrosocial contract is perceived as fair (i.e., "morally objective and unbiased"; Donaldson \& Dunfee, 1994: 260). The question, then, becomes which moral principles can ensure that MSIs' macrosocial contracts are perceived as fair? Future scholarly work needs to look into this question, for instance, by studying whether the inclusion of all affected stakeholders in the development of MSIs' macrosocial contracts can ensure such fairness. For instance, 66 percent of participants in the UNGC stated that one of the reasons for their engagement in the initiative is that the underlying principles are perceived as unbiased and discursively legitimized through the UN system (UN Global Compact, 2010).

\section{Impact: Morally Justifying MSI Impact}

Our review showed the need to study how actors mobilize different moral legitimacy criteria to justify MSIs' impact, and how disputes between actors with different criteria can be resolved. To theorize the existence of different moral legitimacy criteria, we suggest to connect the MSI debate to Boltanski and Thévenot's (2006) theory of justification. At the heart of their theory is the idea to distinguish "common worlds" that are dominated by certain "orders of worth." These orders provide actors in a particular common world with shared moral principles that can be mobilized to justify what they view as morally legitimate. Boltanski \& Thévenot's theory (2006) identified six orders: a civic worth (defined by the collective or general will), a market worth (defined by competition and sales), an industrial worth (defined by efficiency and control of production), the world of fame (defined by the most worthy having high public exposure), the domestic world (defined by stable tradition and hierarchy), and the inspired world (defined by creativity and insight). Later work by Lamont and Thévenot (2000) added the green worth (defined by concerns for sustainability). Together these different orders reflect a framework that explains how actors justify their claims by embedding them in particular moral orders.

One key advantage of the orders-of-worth approach is that it gives reference to specific moral orders, which can explain how certain groups of actors mobilize justifications that are aligned with those moral principles that reflect their particular "common world." The orders-of-worth literature can enrich the discussion of MSIs' impact, as it acknowledges that impact is judged by different audiences with diverse motives and underlying moral principles (see also Ponte, 2016). In other words, this theoretical framing would help recognize the existence of a plurality of competing and contested orders for evaluating MSIs' impact and pair this with a strong focus on the moral foundations of legitimacy. Business ethics scholars would need to identify which kind of actors mobilize what order of worth (or what overlap of plural orders) when evaluating the impact of MSIs. 
This approach would refute the evaluation of MSI impact as a routine task. Rather, it would draw attention to how actor groups engage in "legitimacy tests," which reflect "moments of critical questions in which the worth of particular arrangements needs to be justified" (Patriotta et al., 2011: 1805). MSIs often face such moments when their impact is questioned by different audiences (see, e.g., the public debate around the impacts of biofuel sustainability certification; Ponte, 2014). During these legitimacy tests actors start to mobilize orders of worth in order to justify their position. The frictions that are created when multiple orders of worth are mobilized can lead to disputes (Nyberg \& Wright, 2013), which are supposed to be resolved through dialogue (Boltanski \& Thévenot, 2006). Overcoming such disputes can entail negotiating a compromise, such as when the UNGC introduced new accountability measures after NGOs criticized its impact (Williams, 2004). It can also result in an entirely new moral reference point for evaluation by negotiating a new worth that transcends the two conflicting ones-for instance, when producers and consumers coordinated their mutual expectations on sustainability through personal interaction at farmers' markets, building a "regard convention" (Kirwan, 2006). Future research would need to identify the sites in which such negotiations happen, assess whether they are successful, and study how this influences the evaluation of MSIs' impact.

\section{Business Ethics Research Challenges Across the 3Is}

Surprisingly little research has spanned across all 3Is. In our review, statements about linkages were found to be only rarely the outcome of deliberate theorizing. When linkages were discussed, the effects were mostly framed at a macro/interorganizational level, such as when studies on diffusion patterns also discussed the resulting impact of an MSI (e.g., Marimon et al., 2012). Less well understood are the micro-level foundations of the interaction effects between input, institutionalization, and impact.

We suggest approaching this task by putting the role of individual ethical leadership on the agenda of MSI scholars, and also by suggesting the domain of MSIs as a theme to be explored by ethical leadership scholars. We understand ethical leadership to be "the demonstration of normatively appropriate conduct through personal actions and interpersonal relationships, and the promotion of such conduct to followers through two-way communication, reinforcement, and decision-making" (Brown et al., 2005: 120). A focus on ethical leadership addresses several shortcomings in the MSI literature by: (1) emphasizing the role of individuals within/around MSIs, (2) highlighting that leadership is often required to take moral action related to MSIs (Ciulla et al., 2017), and (3) covering topics that are located at the intersection of the 3Is.

We outline two specific examples of how future research could be conducted. The first example deals with the interaction effects between a key leadership challenge that emerges with regard to input and its effects on institutionalization and impact. MSIs usually operate in environments with high degrees of ethical complexity, i.e., situations where stakeholders disagree about which norms are at stake or which should be prioritized (Reinecke \& Ansari, 2015). For individuals who are steering MSIs this creates a leadership challenge. On the one hand, MSIs need to ensure norm validity by creating mutual agreement among stakeholders. As Patzer et al. (2018: 347) ask, "What do we expect of leaders when they are confronted with 
persistent disagreement, despite an orientation toward consensus building? What does it mean for a leader to moderate different stakeholder groups?" For MSIs, this need for stakeholder integration via deliberation is a key pillar of input legitimacy. On the other hand, leaders in MSIs are requested to balance such integration with commercial pressures and thus many initiatives seek to mainstream and scale up their operations (e.g., by including large-scale buyers; Klooster, 2010). Future scholarly work needs to explore how the (un)successful handling of this leadership challenge influences MSIs' diffusion patterns (institutionalization) and outputs as well as outcomes (impact). Morally disappointing leaders may fail to show "integrative ethical leadership" (Patzer et al., 2018) and thus favor commercial objectives at the expense of input legitimacy. Research also needs to explore the consequences of such leadership behaviors, for example, whether it impacts the legitimacy of institutional designs and whether it influences the adoption of the initiative by mission-driven corporations. Such research would help to expose trade-offs between the 3Is, which have remained mostly unacknowledged to date.

The second example is about the leadership challenge of managing the coexistence of MSIs (institutionalization) and its consequences for input and impact. One way to address coexistence is to integrate the voices of different MSIs and to develop a common normative basis, which would be reflected in either a joint umbrella initiative or a shared framework agreement (Loconto \& Fouilleux, 2014). However, so far, many attempts to develop joint agreements have failed (Fransen, 2011). This shows that the alignment of different (and often competing) MSIs is a significant leadership challenge, which sets high normative expectations for the involved individuals. Relevant actors would not only need to move beyond strategic considerations for their own initiative but also problematize those aspects where moral assessments between initiatives differ. Future research needs to show what type of leaders are required to align the normative basis of different initiatives. For instance, leaders who can create the conditions for discourses among individuals with overlapping but also partly diverging interests increase the likelihood of finding and enacting a compromise (Rasche \& Scherer, 2014). Future scholarly work also has to study the consequences of such leadership behavior for input and impact by asking questions such as: How do the politics related to the development of a joint initiative (input) interact with leaders' ability to create norm-defining discourses that transcend the boundaries of single MSIs? Will newly emerging outputs and outcomes (impact) still be viewed as morally acceptable by different stakeholders? How will leaders develop possible agreements among MSIs into an organization that becomes institutionalized?

\section{EXTENDING BUSINESS ETHICS THEORIES THROUGH MSI RESEARCH}

So far, our discussion has shown how MSI research can be advanced through business ethics theories. We now shift our focus to how new theoretical developments within business ethics scholarship can leverage insights from MSI research. We discuss two streams of literature in business ethics: stakeholder theory (because MSI scholars have explicitly acknowledged it in their research; see Table 5) and human dignity (because many MSIs explicitly promote a focus on dignity). 


\section{Stakeholder Theory}

MSI research can particularly extend what has recently been theorized as "political stakeholder theory" (Olsen, 2017). This stream of research has highlighted states' ability to impact stakeholder legitimacy and managerial choice. Existing scholarship in stakeholder theory mostly sees the state "as one of many stakeholders" (Olsen, 2017: 92) and thereby neglects how this actor can either enhance or limit managerial discretion. MSI studies can advance this recent line of thinking in two ways. First, research can show how governmental agencies and also intergovernmental organizations use MSIs as vehicles to shape stakeholder legitimacy. For instance, the literature on MSIs' impact has stressed that some governments have used relevant initiatives as benchmarks within ongoing policy development, thereby boosting the legitimacy of selected NGOs (e.g., the UK government's decision to endorse the MSC made the WWF a salient stakeholder to firms in the fishery industry; Gale \& Haward, 2011). However, governments can also create external constraints that impact stakeholder legitimacy by rejecting MSIs (e.g., the Icelandic government rejected the MSC and created its own label; Foley, 2013). MSI scholarship can therefore help to examine how state actors influence the perceived legitimacy of certain stakeholder groups, which, in turn, has implications for managerial decision-making.

Second, MSI scholarship also complements political stakeholder theory because it provides an empirical framework in which to explore how the shifting tensions between state and market actors are linked to stakeholder legitimacy. Olsen's (2017) framing of an agonistic political stakeholder theory suggests that stakeholder legitimacy can result from contestation (i.e., that antagonistic relationships between state and market actors can facilitate the creation of moral legitimacy). MSI research explores the processes through which such contestations are linked to legitimacy creation. In particular, research on input and institutionalization have highlighted the existence of relevant antagonistic relations (e.g., in the coffee industry; Moog et al., 2015). This literature shows (a) that MSIs often move through periods of contestation and (re)negotiation between state and market actors (Levy et al., 2016), (b) that such periods are essential when trying to secure moral legitimacy by co-creating relevant norms (Reinecke \& Ansari, 2015), and (c) that the legitimacy impact of contestation is often moderated by whether MSIs have set up robust organizational structures that can cope with the resulting tensions (Garcia-Lopez \& Arizpe, 2010).

\section{Human Dignity}

Recent business ethics research has emphasized the role of human dignity (Kennedy et al., 2016; Westermann-Behaylo et al., 2016). Dignity in general can be described as a category "for all that is of intrinsic value and which cannot be replaced" (Pirson et al., 2016: 466). Human dignity, in particular, can be understood as the universal and inherent capacity of humans to be moral. Research on dignity has found its way into some business ethics debates; most of all in the discussion around business and human rights (Kobrin, 2009) and the creation of dignity-enhancing organizational cultures (Margolis, 2001). MSI studies can enrich this scholarship in at least two ways. First, research on input can expose the difficulties of translating dignity, which is usually seen as a foundational idea underlying human rights (Wettstein, 2012), 
into specific rules. Prior studies have shown that MSIs often struggle to settle on specific rules and that foundational ideas are often "lost in translation" (e.g., Vigneau et al., 2015). This line of research can help to better understand the limits of enacting human dignity in practice (Baumann-Pauly et al., 2017). Considering that some of the largest MSIs base their value proposition on foundational principles related to human dignity (Williams, 2004), such research seems important and timely.

Second, research on MSIs' impact can study whether the adoption of a particular initiative by a firm is able to support the creation of a dignity-enhancing organizational culture. Existing studies have shown that MSI adoption often results in a culture of compliance where participating firms tend to "tick the boxes" without much reflection on the actual intention of the initiative (see, e.g., Rasche, 2010). If some MSIs directly promote human dignity (e.g., the FSC's first and second principle), it is essential to know in what ways, if any, the resulting rules change the cultures of participating organizations. As Margolis (2001: 432-33) rightly observed, we cannot simply assign responsibility to an organization. We need to focus on how the organizational context (e.g., its culture) enables responsible agents with human dignity. Because MSI impact research has studied the contexts and practices of adopting organizations in detail, it is well equipped to discuss what enables and constrains the embeddedness of dignity in organizational life (e.g., by focusing on what makes people capable of treating others as having an inherent worth).

\section{CONCLUSION}

MSIs for sustainability are an important phenomenon, both theoretically (as an empirical context to develop and refine theories) and practically (as a way to address societal challenges that research should tackle). We set out to explore which themes constitute the cross-disciplinary literature around MSIs for sustainability, and how business ethics scholars can contribute to and benefit from this literature in the future. We showed that research on MSIs covers three main themes: the input into creating and governing MSIs; the institutionalization of MSIs; and the impact that relevant initiatives have on sustainability issues. We used these themes as a springboard to identify four research challenges (within and across the 3Is): the need to view norm justification in the context of deliberative systems, the need to reach beyond utilitarian reasoning when studying MSI adoption, the need to morally justify MSI impact, and the need to emphasize the role of individual ethical leadership within MSIs. Our discussion showed that a business ethics perspective can add a distinct quality to the existing polyphonic debates on MSIs—one that provides them with an urgently needed moral connotation. Our review and framing of a future research agenda is thus intended as a call for action for business ethicists to become more involved in research on MSIs, and for scholars from other disciplines to incorporate business ethics perspectives in their thinking and theoretical development.

Our discussion throughout this article rested on the 3I framework. However, future scholarly work on MSIs in business ethics should also reach beyond the 3Is to investigate fully unexplored research directions. Consider the following two examples. First, one aspect that is neglected by current scholarly work is the 
deinstitutionalization of MSIs (Oliver, 1992). While research has much to say about processes of institutionalization, we know almost nothing about what leads to the erosion or even discontinuity of MSIs. For instance, the Marine Aquarium Council was set up in 1998 and ceased to exist in 2008, while the Flower Label Program, which was set up in 1999, stopped its activities in 2011 (Schleifer \& Bloomfield, 2015). For business ethics scholars such cases are interesting, as there is the question of how far deinstitutionalization corresponds with a dissociation of the MSI from its moral foundations (e.g., NGOs or corporate actors may try to adopt dissociative techniques in striving for deinstitutionalization; den Hond \& de Bakker, 2007).

A second aspect reaching beyond the 3I framework is to more closely examine how, when, and why individual and collective decision biases influence the development and execution of MSIs' policies. As with all humans, decision makers in MSIs are influenced by heuristics and biases in various ways. For instance, information and ideas do not enter the agenda of MSIs in a neutral way. The presentation of an issue can determine how it is noticed and interpreted and thus influence its salience (e.g., framing a problem in terms of severe consequences like deaths through human rights violations influences the perceived moral intensity and thus allocation of attention; see, e.g., Jones, 1991). Work on behavioral ethics and social cognition (Bazerman \& Sezer, 2016; Treviño et al., 2006) can be connected to these debates, for example, to uncover how decision biases like confirmation and optimism prejudices, as well as unrecognized default rules, shape MSI decision makers' moral awareness and judgement.

\section{SUPPLEMENTARY MATERIAL}

To view supplementary material for this article, please visit https://doi.org/10.1017/ beq.2019.10

\section{ACKNOWLEDGEMENTS}

An early version of this paper was presented at the EGOS Colloquium in Naples in 2015. We thank the handling editor, Jerry Goodstein, and three anonymous reviewers for their helpful guidance. The "Governing Responsible Business" research environment at Copenhagen Business School provided helpful assistance in the data collection stage.

\section{NOTES}

1. The Business Social Compliance Initiative (BSCI), for instance, is exclusively open to corporations, with other stakeholders having only advisory functions (Egels-Zandén \& Wahlqvist, 2007). Likewise, we deem Responsible Care, the Common Code for the Coffee Community (4C), and the Alliance for Bangladesh Worker Safety as having minimal multi-stakeholder features. Often these business-driven initiatives are launched as industry responses to acute crises (e.g., the Rana Plaza incident in Bangladesh) or to emerging MSIs (e.g., the Program for Endorsement of Forest Certification Schemes, which was launched as a response to the rise of the FSC).

2. One exception is ISO 26000, which is included in our review because the development of this standard was explicitly designed as a multi-stakeholder process (Hahn \& Weidtmann, 2016).

3. An example is Nike's labor code (Locke \& Romis, 2010). 
4. This article was part of our original dataset available "online first" in 2015. It was then published in print in 2018.

5. Another topic that is closely related to outputs and outcomes is the link between MSIs and public regulation. Some studies argue that national legal regulations undermine MSIs, because they incentivize a race to the bottom (Fortin \& Richardson, 2013), while other studies highlight that the acceptance of MSIs by firms is higher when there are stronger public regulatory standards in place (e.g., Büthe, 2010; McCarthy, 2012; Soreide \& Truex, 2013). Also, some studies emphasize that MSIs can help to make existing legal rules more enforceable (e.g., Pattberg, 2006). This research sees MSIs' long-term impact, both in terms of output and outcomes, as being dependent on successful configurations with other regulatory approaches.

6. Thanks to an anonymous reviewer for bringing this to our attention.

\section{REFERENCES}

Aguinis, H., \& Glavas, A. 2012. What we know and don't know about corporate social responsibility: A review and research agenda. Journal of Management, 38: 932-968.

Amer, E. 2018. The penalization of non-communicating UN Global Compact's companies by investors and its implications for this initiative's effectiveness. Business \& Society, 57: 255-291.

Auld, G. 2014. Confronting trade-offs and interactive effects in the choice of policy focus: Specialized versus comprehensive private governance. Regulation and Governance, 8: 126-148.

Auld, G., Renckens, S., \& Cashore, B. 2015. Transnational private governance between the logics of empowerment and control. Regulation and Governance, 9: 108-124.

Bäckstrand, K. 2006. Multi-stakeholder partnerships for sustainable development: Rethinking legitimacy, accountability and effectiveness. European Environment, 16: 290-306.

Barrientos, S., \& Smith, S. 2007. Do workers benefit from ethical trade? Assessing codes of labour practice in global production systems. Third World Quarterly, 28: 713-729.

Bartley, T. 2007. Institutional emergence in an era of globalization: The rise of transnational private regulation of labor and environmental conditions. American Journal of Sociology, 113: 297-351.

Bartley, T. 2014. Transnational governance and the re-centered state: Sustainability or legality? Regulation and Governance, 8: 93-109.

Baumann-Pauly, D., Nolan, J., Van Heerden, A., \& Samway, M. 2017. Industry-specific multi-stakeholder initiatives that govern corporate human rights standards: Legitimacy assessments of the Fair Labor Association and the Global Network Initiative. Journal of Business Ethics, 143: 771-787.

Bazerman, M. H., \& Sezer, O. 2016. Bounded awareness: Implications for ethical decision making. Organizational Behavior and Human Decision Processes, 136: 95-105.

Bear, C., \& Eden, S. 2008. Making space for fish: The regional, network and fluid spaces of fisheries certification. Social and Cultural Geography, 9: 487-504.

Bernstein, S. 2011. Legitimacy in intergovernmental and non-state global governance. Review of International Political Economy, 18: 17-51.

Bieri, F., \& Boli, J. 2011. Trading diamonds responsibly: Institutional explanations for corporate social responsibility. Sociological Forum, 26: 501-526.

Bloomfield, M. J. 2012. Is forest certification a hegemonic force? The FSC and its challengers. Journal of Environment and Development, 21: 391-413.

Boltanski, L., \& Thévenot, L. 2006. On justification: Economies of worth. Princeton, NJ: Princeton University Press. 
Bowen, G. A. 2008. Naturalistic inquiry and the saturation concept: A research note. Qualitative Research, 8: 137-152.

Bowie, N. E. 1998. A Kantian theory of capitalism. Business Ethics Quarterly, 37-60.

Bradley, B. 2006. Two concepts of intrinsic value. Ethical Theory and Moral Practice, 9: 111-130.

Brown, M. E., Treviño, L. K., \& Harrison, D. 2005. Ethical leadership: A social learning perspective for construct development and testing. Organizational Behavior and Human Decision Processes, 97: 117-134.

Bush, S., Toonen, H. M., Oosterveer, P., \& Mol, A. P. J. 2013. The "devils triangle" of MSC certification: Balancing credibility, accessibility and continuous improvement. Marine Policy, 37: 288-293.

Büthe, T. 2010. Private regulation in the global economy: A (p)review. Business and Politics, 12: 1-38.

Cashore, B. 2002. Legitimacy and the privatization of environmental governance: How non-state market-driven (NSMD) governance systems gain rule-making authority. Governance, 15: 503-529.

Cashore, B., van Kooten, G. C., Vertinsky, I., Auld, G., \& Affolderbach, J. 2005. Private or self-regulation? A comparative study of forest certification choices in Canada, the United States and Germany. Forest Policy and Economics, 7: 53-69.

Cheyns, E. 2014. Making "minority voices" heard in transnational roundtables: The role of local NGOs in reintroducing justice and attachments. Agriculture and Human Values, 31: 439-453.

Ciulla, J. B., Knights, D., Mabey, C., \& Tomkins, L. 2017. Philosophical contributions to leadership ethics. Business Ethics Quarterly, 28: 1-14.

Clark, M. R., \& Kozar, J. S. 2011. Comparing sustainable forest management certifications standards: A meta-analysis. Ecology and Society, 16(1).

Corley, K. G., \& Gioia, D. A. 2011. Building theory about theory building: What constitutes a theoretical contribution? Academy of Management Review, 36: 12-32.

Crane, A., \& Matten, D. 2007. Business ethics: Managing corporate citizenship and sustainability in the age of globalization ( $2^{\text {nd }}$ ed.). Oxford, United Kingrom: Oxford University Press.

den Hond, F., \& de Bakker, F. G. A. 2007. Ideologically motivated activism: How activist groups influence corporate social change activities. Academy of Management Review, 32: 901-924.

Det Norske Veritas, \& United Nations Global Compact. 2015. Impact: Transforming business, changing the world: The United Nations Global Compact. New York: United Nations Global Compact Office.

Donaldson, T., \& Dunfee, T. W. 1994. Toward a unified conception of business ethics: Integrative Social Contracts Theory. Academy of Management Review, 19: 252-284.

Dryzek, J. S. 2010. Foundations and frontiers of deliberative governance. Oxford, United Kingdom: Oxford University Press.

Eden, S. 2009. The work of environmental governance networks: Traceability, credibility and certification by the Forest Stewardship Council. Geoforum, 40: 383-394.

Egels-Zandén, N., \& Wahlqvist, E. 2007. Post-partnership strategies for defining corporate responsibility: The business social compliance initiative. Journal of Business Ethics, 70: 175-189.

Elgert, L. 2012. Certified discourse? The politics of developing soy certification standards. Geoforum, 43: 295-304. 
Elstub, S., \& Mclaverty, P. 2014. Conclusion: the future of deliberative democracy. In S. Elstub \& P. Mclaverty (Eds.), Deliberative democracy: Issues and cases: 189-195. Edinburgh: Edinburgh University Press.

Espinoza, O., Buehlmann, U., \& Smith, B. 2012. Forest certification and green building standards: Overview and use in the U.S. hardwood industry. Journal of Cleaner Production, 33: 30-41.

Etzion, D., \& Ferraro, F. 2010. The role of analogy in the institutionalization of sustainability reporting. Organization Science, 21: 1092-1107.

Everett, D., Martinez, D., \& Neu, J. S. 2008. Multi-stakeholder labour monitoring organizations: Egoists, instrumentalists, or moralists? Journal of Business Ethics, 81: 117-142.

Foley, P. 2013. National government responses to Marine Stewardship Council (MSC) fisheries certification: Insights from Atlantic Canada. New Political Economy, 18: 284-307.

Fortin, E. 2013. Transnational multi-stakeholder sustainability standards and biofuels: Understanding standards processes. Journal of Peasant Studies, 40: 563-587.

Fortin, E., \& Richardson, B. 2013. Certification schemes and the governance of land: Enforcing standards or enabling scrutiny? Globalizations, 10: 141-159.

Fransen, L. 2012. Multi-stakeholder governance and voluntary programme interactions: Legitimation politics in the institutional design of corporate social responsibility. Socio-Economic Review, 10: 163-192.

Fransen, L., \& Burgoon, B. 2014. Privatizing or socializing corporate responsibility: Business participation in voluntary programs. Business \& Society, 53: 583-619.

Fransen, L. W., \& Kolk, A. 2007. Global rule-setting for business: A critical analysis of multi-stakeholder standards. Organization, 14, 667-684.

Frynas, J. G., \& Yamahaki, C. 2016. Corporate social responsibility: Review and roadmap of theoretical perspectives. Business Ethics: A European Review, 25: 258-285.

Gale, F. 2014. Four models of interest mediation in global environmental governance. Global Policy, 5: 10-22.

Gale, F., \& Haward, M. 2011. Global commodity governance: State responses to sustainable forest and fisheries certification. Basingstoke, United Kingdom: Palgrave Macmillan.

García-López, G., \& Arizpe, N. 2010. Participatory processes in the soy conflicts in Paraguay and Argentina. Ecological Economics, 70: 196-206.

Gilbert, D. U. \& Behnam, M. 2009. Advancing integrative social contracts theory: A Habermasian perspective. Journal of Business Ethics, 89: 215-234.

Gilbert, D. U., \& Rasche, A. 2007. Discourse ethics and social accountability: The ethics of SA 8000. Business Ethics Quarterly, 17: 187-216.

Gilbert, D. U., Rasche, A., \& Waddock, S. 2011. Accountability in a global economy: The emergence of international accountability standards. Business Ethics Quarterly, 21: 23-44.

Goffman, E. 1959. The presentation of self in everyday life. New York: Doubleday.

Gulbrandsen, L. H. 2008. Accountability arrangements in non-state standards organizations: Instrumental design and imitation. Organization, 15: 563-583.

Gulbrandsen, L. H. 2009. The emergence and effectiveness of the Marine Stewardship Council. Marine Policy, 33: 654-660.

Haack, P., Pfarrer, M. D., \& Scherer, A. G. 2014. Legitimacy-as-feeling: How affect leads to vertical legitimacy spillovers in transnational governance. Journal of Management Studies, 51: 634-666.

Haack, P., \& Scherer, A. G. 2014. Why sparing the rod does not spoil the child: A critique of the "strict father" model in transnational governance. Journal of Business Ethics, 122: $225-240$. 
Haack, P., Schoeneborn, D., \& Wickert, C. 2012. Talking the talk, moral entrapment, creeping commitment? Exploring narrative dynamics in corporate responsibility standardization. Organization Studies, 33: 815-845.

Hahn, R., \& Weidtmann, C. 2016. Transnational governance, deliberative democracy, and the legitimacy of ISO 26000. Business \& Society, 55: 90-129.

Hale, A., \& Opondo, M. 2005. Humanising the cut flower chain: Confronting the realities of flower production for workers in Kenya. Antipode, 37: 301-323.

Hatanaka, M. 2010. Certification, partnership, and morality in an organic shrimp network: Rethinking transnational alternative agrifood networks. World Development, 38: 706-716.

Hatanaka, M., Konefal, J., \& Constance, D. H. 2012. A tripartite standards regime analysis of the contested development of a sustainable agriculture standard. Agriculture and Human Values, 29: 65-78.

Heras-Saizarbitoria, I., \& Boiral, O. 2013. ISO 9001 and ISO 14001: Towards a research agenda on management system standards. International Journal of Management Reviews, 15: 47-65.

Johansson, J. 2014. Why do forest companies change their CSR strategies? Responses to market demands and public regulation through dual-certification. Journal of Environmental Planning and Management, 57: 349-368.

Jones, T. M. 1991. Ethical decision making by individuals in organizations: An issuecontingent model. Academy of Management Review, 16: 366-395.

Kant, I. 1785 (1990). Foundations of the metaphysics of morals. New York: Macmillan.

Kennedy, J. A., Kim, T. W., \& Strudler, A. 2016. Hierarchies and dignity: A Confucian communitarian approach. Business Ethics Quarterly, 26: 479-502.

Ketokivi, M., \& Mantere, S. 2010. Two strategies for inductive reasoning in organizational research. Academy of Management Review, 35: 315-333.

Kirwan, J. 2006. The interpersonal world of direct marketing: examining conventions of quality at UK farmers' markets. Journal of Rural Studies 22: 301-312.

Klooster, D. 2006. Environmental certification of forests in Mexico: The political ecology of a nongovernmental market intervention. Annals of the Association of American Geographers, 96: 541-565.

Klooster, D. 2010. Standardizing sustainable development? The Forest Stewardship Council's plantation policy review process as neoliberal environmental governance. Geoforum, 41: 117-129.

Knudsen, J. 2011. Company delistings from the UN Global Compact: Limited business demand or domestic governance failure? Journal of Business Ethics, 103: 331-349.

Kobrin, S. J. 2009. Private political authority and public responsibility: Transnational politics, transnational firms, and human rights. Business Ethics Quarterly, 19: 349-374.

Kohne, M. 2014. Multi-stakeholder initiative governance as assemblage: Roundtable on sustainable palm oil as a political resource in land conflicts related to oil palm plantations. Agriculture and Human Values, 31: 469-480.

Kolk, A., \& van Tulder, R. 2002. Child labor and multinational conduct: A comparison of international business and stakeholder codes. Journal of Business Ethics, 36: 291-301.

Lambin, E. F., \& Thorlakson, T. 2018. Sustainability standards: Interactions between private actors, civil society, and governments. Annual Review of Environment and Resources, 43: 6.1-6.25.

Lamont, M., \& Thévenot, L. 2000. Rethinking comparative cultural sociology. Cambridge, United Kingdom: Cambridge University Press. 
Levy, D. L., Brown, H. S., \& de Jong, M. 2010. The contested politics of corporate governance: The case of the Global Reporting Initiative. Business \& Society, 49: 88-115.

Levy, D., Reinecke, J., \& Manning, S. 2016. The political dynamics of sustainable coffee: Contested value regimes and the transformation of sustainability. Journal of Management Studies, 53: 364-401.

Llach, J., Marimon, F., \& Alonso-Almeida, M. D. M. 2015. Social Accountability 8000 standard certification: Analysis of worldwide diffusion. Journal of Cleaner Production, 93: 288-298.

Locke, R. M., \& Romis, M. 2010. The promise and perils of private voluntary regulation: Labor standards and work organization in two Mexican garment factories. Review of International Political Economy, 17: 45-74.

Loconto, A., \& Fouilleux, E. 2014. Politics of private regulation: ISEAL and the shaping of transnational sustainability governance. Regulation \& Governance, 8: 166-185.

Manning, S., Boons, F., von Hagen, O., \& Reinecke, J. 2012. National contexts matter: The co-evolution of sustainability standards in global value chains. Ecological Economics, 83: 197-209.

Manning, S., \& von Hagen, O. 2010. Linking local experiments to global standards: How project networks promote global institution-building. Scandinavian Journal of Management, 26: 398-416.

Mansbridge, J., Bohman, J., Chambers, S., Christiano, T., Fung, A., Parkinson, J., Thompson, D. F., \& Warren, M. E. 2012. A systemic approach to deliberative democracy. In J. Parkinson \& J. Mansbridge (Eds.), Deliberative systems: 1-26. Cambridge, United Kingdom: Cambridge University Press.

Margolis, J. D. 2001. Responsibility in organizational context. Business Ethics Quarterly, 11: 431-454.

Marimon, F., Alonso-Almeida, M. M., Rodríguez, M. P., \& Cortez Alejandro, K. A. 2012. The worldwide diffusion of the global reporting initiative: What is the point? Journal of Cleaner Production, 33: 132-144.

Marx, A. 2008. Limits to non-state market regulation: A qualitative comparative analysis of the international sport footwear industry and the Fair Labor Association. Regulation and Governance, 2: 253-273.

Marx, A., \& Cuypers, D. 2010. Forest certification as a global environmental governance tool: What is the macro-effectiveness of the Forest Stewardship Council? Regulation and Governance, 4: 408-434.

Mayntz, R. 2010. Legitimacy and compliance in transnational governance. Working Paper 10/5. Cologne: Max Planck Institute for the Study of Societies.

McCarthy, J. F. 2012. Certifying in contested spaces: Private regulation in Indonesian forestry and palm oil. Third World Quarterly, 33: 1871-1888.

Mena, S., \& Palazzo, G. 2012. Input and output legitimacy of multi-stakeholder initiatives. Business Ethics Quarterly, 22: 527-556.

Miles, M. P., \& Munilla, L. S. 2004. The potential impact of social accountability certification on marketing: A short note. Journal of Business Ethics, 50: 1-11.

Miller, A. M., \& Bush, S. R. 2015. Authority without credibility? Competition and conflict between ecolabels in tuna fisheries. Journal of Cleaner Production, 107: 137-145.

Miteva, D. A., Loucks, C. J., \& Pattanayak, S. K. 2015. Social and environmental impacts of forest management certification in Indonesia. PloS one, 10(7).

Moog, S., Spicer, A., \& Böhm, S. 2015. The politics of multi-stakeholder initiatives: The crisis of the Forest Stewardship Council. Journal of Business Ethics, 128: 469-493. 
MSI Integrity. 2017. The new regulators? Assessing the landscape of multi-stakeholder initiatives. San Francisco: MSI Integrity (with the Duke Human Rights Center).

Nebel, G., Quevedo, L., Bredahl Jacobsen, J., \& Helles, F. 2005. Development and economic significance of forest certification: The case of FSC in Bolivia. Forest Policy and Economics, 7: 175-186.

Nelson, V., \& Tallontire, A. 2014. Battlefields of ideas: Changing narratives and power dynamics in private standards in global agricultural value chains. Agriculture and Human Values, 31: 481-497.

Nesadurai, H. E. S. 2013. Food security, the palm oil-land conflict nexus, and sustainability: A governance role for a private multi-stakeholder regime like the RSPO? Pacific Review, 26: 505-529.

Nicholls, A., \& Huybrechts, B. 2016. Sustaining inter-organizational relationships across institutional logics and power asymmetries: The case of fair trade. Journal of Business Ethics, 135: 699-714.

Nyberg, D., \& Wright, C. 2013. Corporate corruption of the environment: Sustainability as a process of compromise. British Journal of Sociology, 64: 405-424.

O'Rourke, D. 2006. Multi-stakeholder regulation: Privatizing or socializing global labor standards? World Development, 34: 899-918.

Oliver, C. 1992. The antecedents of deinstitutionalization. Organization Studies, 13: 563-588.

Overdevest, C., \& Zeitlin, J. 2014. Assembling an experimentalist regime: Transnational governance interactions in the forest sector. Regulation and Governance, 8: 22-48.

Palazzo, G., \& Scherer, A. G. 2006. Corporate legitimacy as deliberation: A communicative framework. Journal of Business Ethics, 66: 71-88.

Partzsch, L. 2011. The legitimacy of biofuel certification. Agriculture and Human Values, 28: 413-425.

Patriotta, G., Gond, J.-P., \& Schultz, F. 2011. Maintaining legitimacy: Controversies, orders of worth, and public justifications. Journal of Management Studies, 48: 1804-1836.

Pattberg, P. 2005. The Forest Stewardship Council: Risk and potential of private forest governance. Journal of Environment and Development, 14: 356-374.

Pattberg, P. 2006. Private governance and the South: Lessons from global forest politics. Third World Quarterly, 27: 579-593.

Patzer, M., Voegtlin, C., \& Scherer, A. G. 2018. The normative justification of integrative stakeholder engagement: A Habermasian view on responsible leadership. Business Ethics Quarterly, 28: 325-354.

Pichler, M. 2013. "People, Planet and Profit": Consumer-oriented hegemony and power relations in palm oil and agrofuel certification. Journal of Environment and Development, 22: 370-390.

Pirson, M., Goodpaster, K., \& Dierksmeier, C. 2016. Human dignity and business. Business Ethics Quarterly, 26: 465-478.

Ponte, S. 2008. Greener than thou: The political economy of fish ecolabeling and its local manifestations in South Africa. World Development, 36: 159-175.

Ponte, S. 2012. The Marine Stewardship Council (MSC) and the making of a market for "sustainable fish." Journal of Agrarian Change, 12: 300-315.

Ponte, S. 2014. "Roundtabling" sustainability: Lessons from the biofuel industry. Geoforum, 54: 261-271.

Ponte, S. 2016. Convention theory in the Anglophone agro-food literature: Past, present and future. Journal of Rural Studies, 44: 12-23.

Ponte, S., \& Cheyns, E. 2013. Voluntary standards, expert knowledge and the governance of sustainability networks. Global Networks, 13: 459-477. 
Prado, A. M. 2013. Competition among self-regulatory institutions: Sustainability certifications in the cut-flower industry. Business \& Society, 52: 686-707.

Rasche, A. 2009. "A necessary supplement": What the United Nations Global Compact is and is not. Business \& Society, 48: 511-537.

Rasche, A. 2010. The limits of corporate responsibility standards. Business Ethics: A European Review, 19: 280-291.

Rasche, A. 2012. Global policies and local practice: Loose and tight couplings in multistakeholder initiatives. Business Ethics Quarterly, 22: 679-708.

Rasche, A., \& Scherer A. G. 2014. Jürgen Habermas and organization studies: Contributions and future prospects. In P. Adler, P. du Gay, G. Morgan, \& M. Reed, M. (Eds.) Oxford handbook of sociology, social theory, and organization studies: 158-181. Oxford, United Kingdom: Oxford University Press.

Rawls. J. 1971. A theory of justice. Cambridge, MA: Harvard University Press.

Raynolds, L. T. 2009. Mainstreaming fair trade coffee: From partnership to traceability. World Development, 37: 1083-1093.

Raynolds, L. T. 2014. Fairtrade, certification, and labor: Global and local tensions in improving conditions for agricultural workers. Agriculture and Human Values, 31: 499-511.

Reinecke, J., \& Ansari, S. 2015. What is a "fair" price? Ethics as sensemaking. Organization Science, 26: 867-888.

Reinecke, J., Manning, S., \& von Hagen, O. 2012. The emergence of a standards market: Multiplicity of sustainability standards in the global coffee industry. Organization Studies, 33: 791-814.

Reinecke, J., van Bommel, K., \& Spicer, A. 2017. When orders of worth clash: Negotiating legitimacy in situations of moral multiplexity. Research in the Sociology of Organizations, 52: 33-72.

Reynolds, S. J., \& Bowie, N. E. 2004. A Kantian perspective on the characteristics of ethics programs. Business Ethics Quarterly, 14: 275-292.

Riisgaard, L. 2011. Towards more stringent sustainability standards? Trends in the cut flower industry. Review of African Political Economy, 38: 435-453.

Ruef, M., \& Scott, W. R. 1998. A multidimensional model of organizational legitimacy: Hospital survival in changing institutional environments. Administrative Science Quarterly, 43: 877-904.

Schepers, D. 2010. Challenges to legitimacy at the Forest Stewardship Council. Journal of Business Ethics, 92: 279-290.

Schleifer, P., \& Bloomfield, M. 2015. When institutions fail: Legitimacy, (de)legitimation, and the failure of private governance systems. European University Institute, Robert Schuman Centre for Advanced Studies Working Paper 2015/36.

Schouten, G., \& Glasbergen, P. 2012. Private multi-stakeholder governance in the agricultural market place: An analysis of legitimization processes of the roundtables on sustainable palm oil and responsible soy. International Food and Agribusiness Management Review, 15B: 63-88.

Schouten, G., Leroy, P., \& Glasbergen, P. 2012. On the deliberative capacity of private multi-stakeholder governance: The roundtables on responsible soy and sustainable palm oil. Ecological Economics, 83: 42-50.

Schwartz, B., \& Tilling, K. 2009. "ISO-lating" corporate social responsibility in the organizational context: A dissenting interpretation of ISO 26000. Corporate Social Responsibility and Environmental Management, 16: 289-299. 
Selfa, T., Bain, C., \& Moreno, R. 2014. Depoliticizing land and water 'grabs' in Colombia: The limits of Bonsucro certification for enhancing sustainable biofuel practices. Agriculture and Human Values, 31: 455-468.

Sethi, S. P., \& Schepers, D. H. 2014. United Nations Global Compact: The promiseperformance gap. Journal of Business Ethics, 122: 193-208.

Singer, P. 1993. Practical ethics ( $2^{\text {nd }}$ ed.). Cambridge: Cambridge University Press.

Slager, R., Gond, J.-P., \& Moon, J. 2012. Standardization as institutional work: The regulatory power of a responsible investment standard. Organization Studies, 33: 763-790.

Soreide, T., \& Truex, R. 2013. Multi-stakeholder groups for better sector performance: A key to fighting corruption in natural-resource governance? Development Policy Review, 31: 203-217.

Starik, M. 1995. Should trees have managerial standing? Toward stakeholder status for non-human nature. Journal of Business Ethics, 14: 207-217.

Strauss A. L., \& Corbin, J. M. 1998. Basics of qualitative research: Techniques and procedures for developing grounded theory ( $2^{\text {nd }}$ ed.). Thousand Oaks, CA: Sage.

Suchman, M. C. 1995. Managing legitimacy: Strategic and institutional approaches. Academy of Management Review, 20: 571-610.

Suddaby, R., Bitektine, A., \& Haack, P. 2017. Legitimacy. Academy of Management Annals, 11: 451-478.

Tamm-Hallström, K. 2008. ISO expands its business into social responsibility. In M. Boström \& C. Garsten (Eds.), Organizing transnational accountability: 46-60. Cheltenham, United Kingdom: Edward Elgar.

Treviño, L. K., Weaver, G. R., \& Reynolds, S. J. 2006. Behavioral ethics in organizations: A review. Journal of Management, 32: 951-990.

UN Global Compact. 2010. UN Global Compact annual review 2010. New York: United Nations.

Verbruggen, P. 2013. Gorillas in the closet? Public and private actors in the enforcement of transnational private regulation. Regulation and Governance, 7: 512-532.

Vigneau, L., Humphreys, M., \& Moon, J. 2015. How do firms comply with international sustainability standards? Processes and consequences of adopting the Global Reporting Initiative. Journal of Business Ethics, 131: 469-486.

Vogel, D. 2008. Private global business regulation. Annual Review of Political Science, 11: 261-282.

Westermann-Behaylo, M. K., Van Buren, H. J., \& Berman, S. L. 2016. Stakeholder capability enhancement as a path to promote human dignity and cooperative advantage. Business Ethics Quarterly, 26: 529-555.

Wettstein, F. 2012. CSR and the debate on business and human rights: Bridging the Great Divide. Business Ethics Quarterly, 22: 739-770.

Whiteman, G., Walker, B., \& Perego, P. 2013. Planetary boundaries: Ecological foundations for corporate sustainability. Journal of Management Studies, 50: 307-336.

Wijen, F. 2014. Means versus ends in opaque institutional fields: Trading off compliance and achievement in sustainability standard adoption. Academy of Management Review, 39: 302-323.

Williams, O. F. 2004. The UN Global Compact: The challenge and the promise. Business Ethics Quarterly, 14: 755-774. 